\title{
EFEITO DO DOSSEL VEGETATIVO NA ESTIMATIVA DO CONSUMO DE ÁGUA E COEFICIENTE DE CULTURA DA ERVILHA (PISUm sativum L.)
}

ANA ClíAUdia ARAÚJO DE MELLO

Orientador: Dr. FLÁAVIO BUSSMEYER ARRUDA

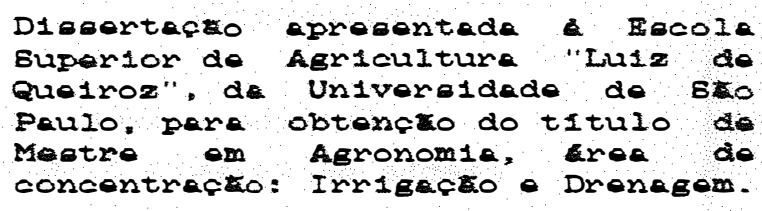

$P$ I R A I C A B A

Estado de Sáo Paulo - Brasil

Junho - 1992 


\section{Ficha catalográfica preparada pela Seção de Livros da}

Divisão de Biblioteca e Documentação - PCAP/USP

Me11o. Ana Cláudia Araújo de M527e Efeito do dossel vegetativo na estimativa do consumo de água e coeficiente de cultura da ervilha. Piracicaba, 1992.

$75 p$.

Diss.(Mestre) - ESALQ

Bibliografia

1. Ervilha - Agua - Consumo 2. Ervilha - Coeficiente de cultura 3. Ervilha - Irrigação I. Escola Superior de Agricultura Luiz de Queiróz, Piracicaba

CDD 635.656 


\section{EFEITO DO DOSSEL VEGETATIVO NA ESTIMATIVA DO CONSUMO DE ÁGUA B COEFICIENTE DE CULTURA DA ERVILHA (Pisum sativum L.)}

aNA CLÁUdia ARAúJo DE MELLIO

Aprovada em: 07.08 .92

Comissa julgadora:

Dr. Elávio Bussmeyer Arruda................... IAC

Prof. Dr. Tarlei Arriel Botrel............. ESALQ/USP

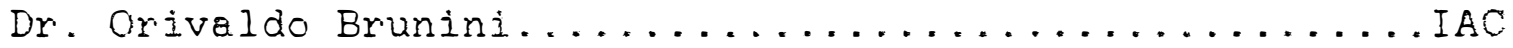

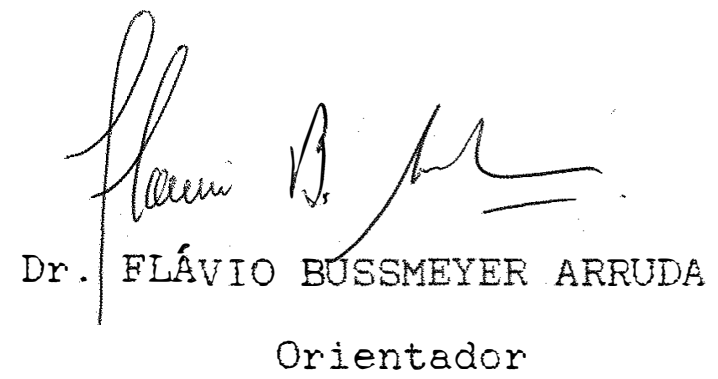


Ao meu esposo Francisco

enosso fitho Mateus

e mens pais

Albanita $e$ Rodrigo

dedico este trabalho. 


\section{A GRADECIMENTOS}

Ao mel esposo Francisco e nosso filho Mateus, que através do amor, amiaade, apoio e compreensäo, tornaram possivel a realizacăo deste trabalho:

Ao pesquisador Dr. Flávio Bussmeyer Arruda, pela or ientaGéo, amizade e valioso incentivo durante todas as fases deste trabalho:

AO CNPq a a FAPESP por terem tornado viável nosso trabalho através da concessäo de recursos:

Ao Curso de Pós-Giraduacáo em Irrigacáo e Drenagem da ESALQUSP, pela possibilidade em realizar o curso:

Aos professores do Curso de Pós-Graduacto en Irrigacáo e Drenagem da ESALQNUSP, pelos conhecimentos adquiridos:

Ao professor da ESALQ/USP Dr. Tarlei Arriel Botrel, peio apoio e sugestöes:

Ao pesquisador do IAC Hamor Fujiwara. pelo apolo e cooperacaco durante os trabalhos de campo: 
Ao Instituto Agronômico do Estado de Säo Paulo (IAC), PE-las facilidades e oportunidades concedidas:

Aos colegas pesquisadores e funcionários da Segäo de Irri-... gacăo e Drenagem do Instituto Agronômico (IAC), pelo ótimo convivio, apoio, sugestöes e auxilio durante todas as fa... ses deste trabalho:

今 Segão de Leguminosas do Instituto Agronômico, em especial aos pesquisadores Elaine Bahia Wutke edmilson J. Ambrosano pelo apoio e concessäo de material na execucáo deste trabalho:

¿ Sefäo de Climatologia Agricola do Instituto Agronômico, pela concessấo de dados meteorológicos:

Ao Departamento de Engenharia Agricola da Universidade Fedetal da paraiba (UFPb), pelo incentivo e cooperacáo no inicio do curso:

Aos colegas do curso de Pós-Graduafăo em Irrigacăo e Drenagem, pela conviventia agradável;

Aos funcionarios do Departamento de Engenharia kural da ESALQ, en especial a Gilmar, José e Hélio, pela cooperacăo nos trabalhos de campo e laboratórios ao longo do curso: 
A professora Albanita Guerra Araijo pela correcão de vernáculo:

A bibliotecária Kátia Maria Andrade Ferraz, pela correcáo das referências bibliográficas:

A familia Matos Pires, em especial a Regina Célia, pelas sugestöes, amizade, estimulo e cooperacăo ao longo de to... dos os anos de convivio:

A todos aqueles que, direta ou indiretamente, contribuiram para o sucesso deste trabalho, porén aqui näo foram citados, o meu sincero agradec imento. 
SUMAR IO

Pág ima

LISTA DE TABELAS ............................

LISTA DE FIGURAS $\ldots \ldots \ldots \ldots \ldots \ldots \ldots \ldots \ldots \ldots \ldots \ldots$

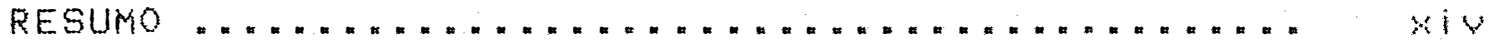

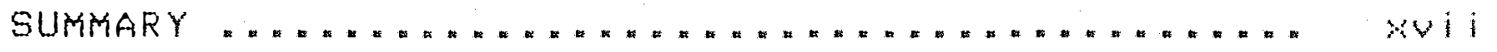

L. INTRODUGAO

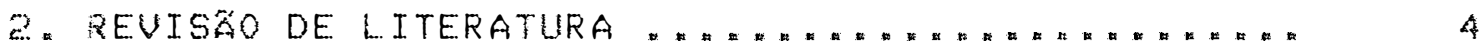

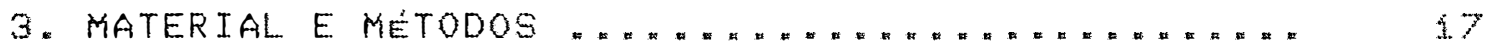

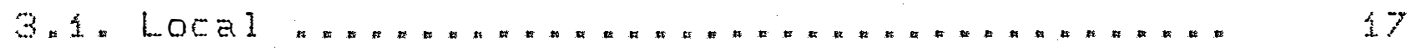

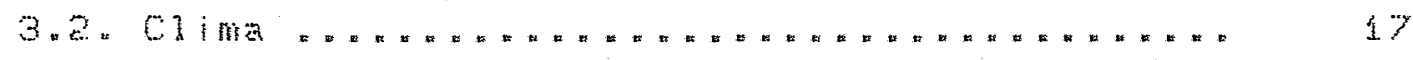

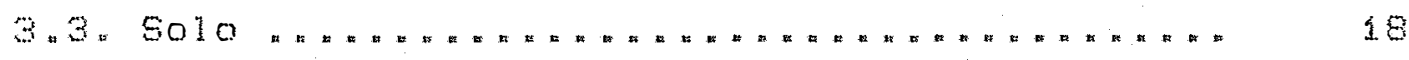

$3.3 \ldots$. Textura e densidade ............

3.3.2. Curva de retengáo de água w....... u 
Página

3.3.3. Condutividade nidráulica ..........

3.4. Cultura .............................. 2

3.5. Del ineamento experimental .............. 22

3.6. Instalacăo e conducăo do experimento ......

3.7. Balanco hidrico .......................... .

3.7.1. Variagáo no armażenanento de água no

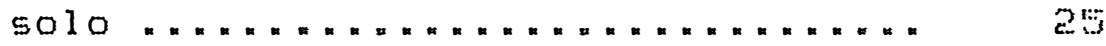

3.7.2. Precipitacăo pluvial e irrigafăo... 26

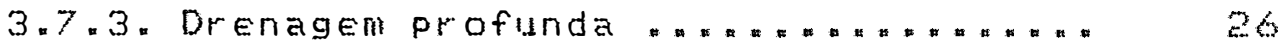

3.7.4. Evapotranspiracäo real (ETr) ......

3.8. Evapotranspiracão de referência (ETo) . . . . 28 3.8.1. Método do Tanque CIasse A (ETOA) ... 28 3.8.2. Método de Pennan modificado (ETopn

3.9. Coeficiente de cultura "... ".............. 30

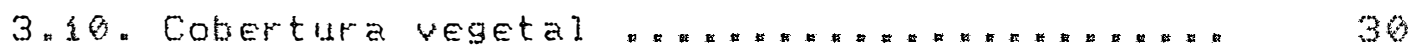

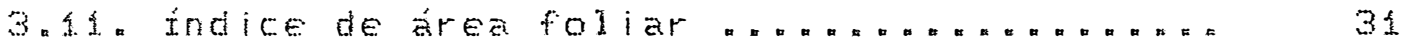

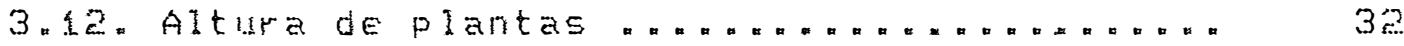

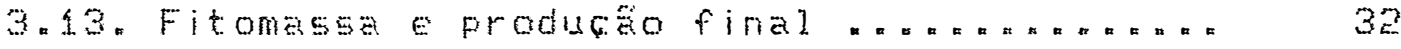

4. RESULTADOS E DISCUSS\%0 \#...................

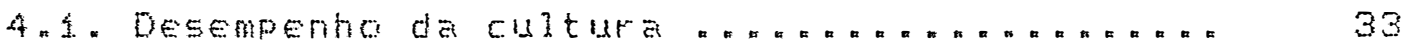

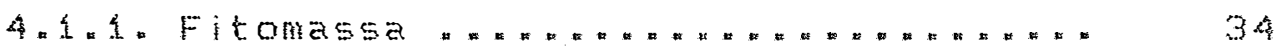

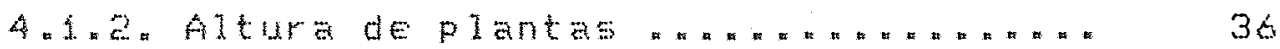

4. l. 3. Indice de área foliar ............ 30 
Página

4.1.4. Cobertura vegetal ................ 40

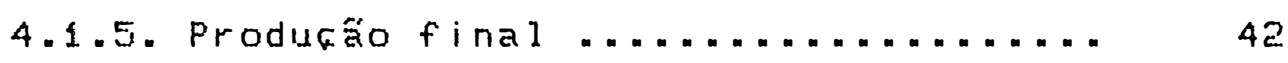

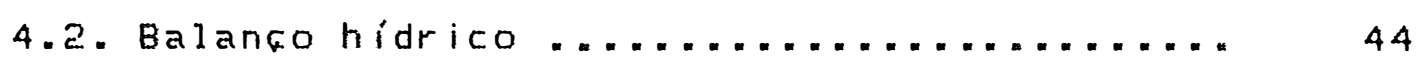

4.3. Coeficiente de cultura ................... 48

4.3.1. Relacấo entre o coeficiente de cultura basal, a porcentagem de cobertura vegetal e o indice de area fo-

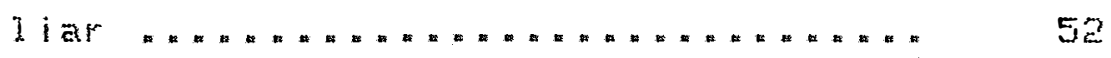

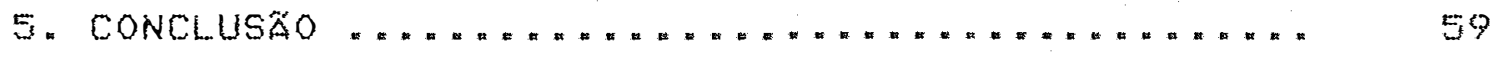

REFERENCIAS BIBLIOGRAFICAS \#..................

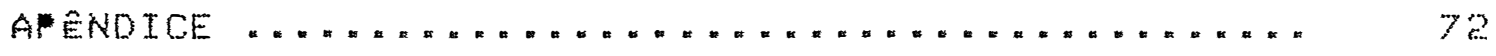




\section{LISTA DE TABELAS}

Tabela

Pág ina

1 Resultados da análise fisica do latossolo roxo, série taquaral, Campinas, SP. ...........

2. Parâmetros da curva de retencáo de água no solo, para seis profundidades do latossolo roxo, série taquaral, segundo o modelo de Van Genuchten $(1980) \ldots \ldots \ldots \ldots \ldots \ldots \ldots \ldots$

3 Equacóes de regressáo linear para os tratamentos de diferentes densidades populacionais da cultura da ervilha, para o ano de 1991. Campinas, SP.

4 Producáo final de gráos (kg/ha) para a cultura da ervilha, nos diferentes tratamentos,pa-

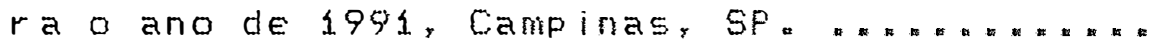

5 Componentes da producáo para a cultura da ervilha, nos diferentes tratamentos, para o ano

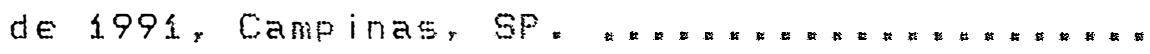


6 Componentes do balanco hidrico de campo - precipitacăo, irrigacáo, variacăo do armazenamento de água no solo ( $\mathbf{A} A)$, drenagem profun-da e evapotranspiracão real (ETr) na cultura da ervilha, para o tratamento de densidade de semeadura de 146 plantas/me, Campi-

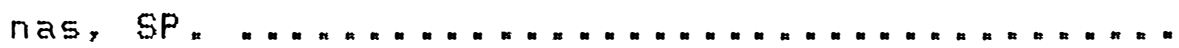

7 Componentes do balango hidrico de campo - pre cipitagáo, irrigafăo, variagáo do armażenamento de água no solo ( $A A)$, drenagem profunda e evapotranspiractio real (ETr) na cultura da ervilha, para o tratamento de densida... de de semeadura de 50 plantas/men, Campinas, SP= 45

8 Componentes do balanco hidrico de campo - pre-cipitaço, irrigaço, variaço do armazenamento de água no solo (AA), drenagem profunda e evapotranspirafáo real (ETr) na cultura da ervilha, para o tratamento de densidade de semeadura de 36 piantasime, Campinas, sp. 46 
$x \dot{x}$

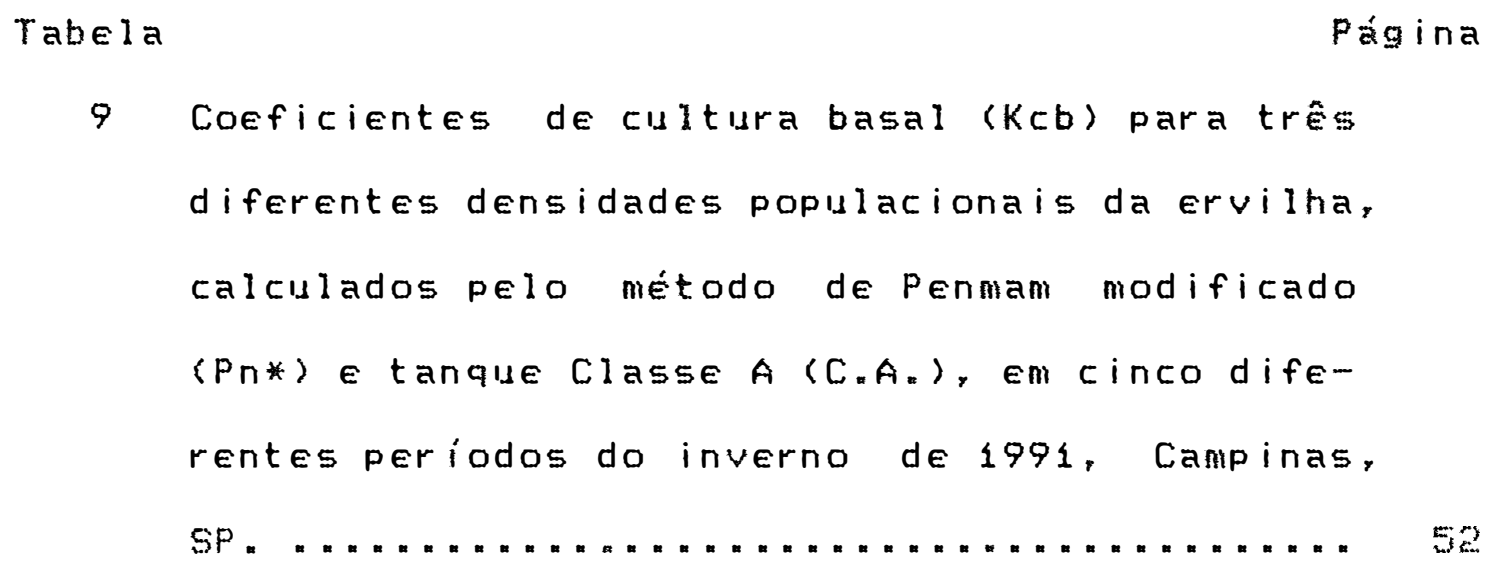




\section{LISTA DE FIGURAS}

Figura

Página

1 Acimulo da matéria seca $\left(g / m^{2}\right)$ ao longo do ciclo de desenvolvimento da cultura da erviIha, para as diferentes populacóes, no ano de 1991, Campinas, SP.

2 Altura de plantas (cm) ao longo do ciclo de desenvolvimento da cultura da ervilha, para as diferentes populacóes, no ano de 1991, Cam...

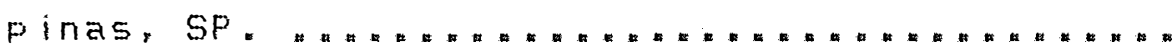

3 Indice de área fol iar (IAF) ao longo do ciclo de desenvolvimento da cultura da ervilha, para as diferentes populacóes, no ano de 1991 , Cam-...

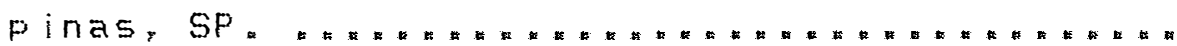

4 Cobertura vegetal $(\%)$ ao longo do ciclo de desenvolvimento da cultura da ervilha, para as diferentes populacbes, no ano de 1991, Cam-..

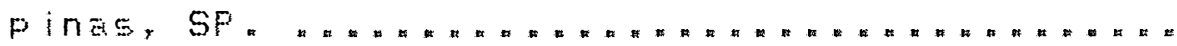


Figura

Coeficiente de cultura basal, calculado pelo método de Penmam modificado kcb(Pn*), desde o início do florescimento até o final do ciclo da cultura da ervilha, para as diferentes po... pulacóes, no ano de 1991, Campinas, SP. "......

6 Coeficiente de cultura basal, calculado pelo método de Penmam modificado kcb(Pn*) (Fig.5) em funcáo da cobertura vegetal (Fig.4), para - intervalo de 30 a 49 dias após a emergência,

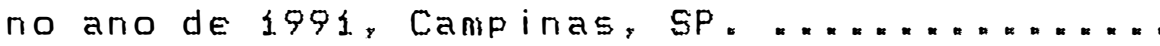

7 Coeficiente de cultura basal, calculado pelo método de Penman modificado kcb(Pn*) (Fig.5) para as diferentes densidades populacionais da cultura da ervilha, em funcaso do indice de área foliar ( $\mathrm{Fig} .3$ ), para o intervalo de 30 a 49 dias após a emergência, no ano de 199.

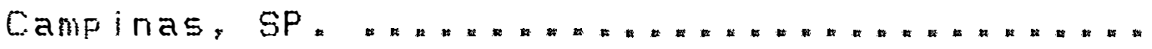




\title{
EFEITO DO DOSSEL VEGETATIVO NA ESTIMATIUA \\ DO CONSUMO DE AGUA E COEFICIENTE DE CULTURA DA \\ ERUILHA (Pisum sativum L.)
}

\author{
Autora: ANA CLAUDIA ARAúJO DE MELLO \\ Orientador: Dr. FLAUIO BUSSMEYER ARRUDA
}

RESUMO

- presente trabalho teve como objetivo in-vestigar o coeficiente de cultura basal (kcb) (BURMAN et ali i, 1980; WRIGHT, 1982) da Ervilha (Pisum sativum L.) cV Majestic, em relatáo ao desenvolvimento do dossel vegetat: ivo da cultura, medido através do indice de area foliar (IAF) e porcentagen de cobertura vegetal (\%CVeg.).

Um ensaio de campo com quatro populacón (36. 50, 8j e 146 plantas/me) foi conduzido no centro Experimental de Campinas - Instituto Agronómico do Estado de:

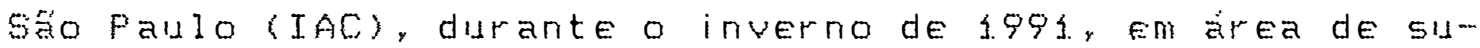
perficie plana de latossolo roxo, série taquaral. Inicial -.. mente, determinaram-se os parâmetros fisico-hidricos do solo, Ea longo do ciclo da cultura, for am medidos os se-.guintes park̂metros: cobertura vegetaly indice de area fo- 
liar, altura de plantas, fitomassa eproducáo final nos tratanentos de diferentes densidades populacionais. O consumo de água foi determinado para os tratamentos de densi-dades populacionais de 36.50 e 146 plantas/me?. As irriga-.. cö́s foram realizadas quando a tensäo de água no solo atingia 60kPa, a $15 c m$ de profundidade, baseado no trata-mento de maior densidade populacional, 146 plantas/m?".

A evapotranspiracäo real (ETr) da cultura foi determinada pela técnica do balanco hidrico de campo. para periodos entre duas irrigacóes. A evapotranspiracáo de referência (ETo) foi estimada pelos métodos do tanque Classe A e Penman modificado, comvistas à obtencáo do coeficiente de cultura basal.

Os resultados mostraram que houve acentuado efeito positivo da densidade populacional sobre a produti.... vidade da ervilha cv Majestic; porém, também aumentou a ocorência de acamamento.

o consumo de água pela cultura, assim como os valores do kcb, variaram com o desenvolvimento da cul... tura, de acordo com as diferencas de densidades populacionais, e com o método de cálculo da evapotranspiraço de referência (ETo).

Os valores medios do coeficiente de cultura (kc), propostos pela FAO (DOORENBOS \& PRUTTT, 49TT), Säo superiores aos valores de kcb determinados neste estudo. 
sobretudo, para o período do início do florescimento até o final da formacấo da producâo.

- coeficiente de cultura basal mostrou-se correlacionado ao indice de área foliar $(r=0,78)$ e à porcentagem de cobertura vegetal $(r=0,85)$. A obtencáo de resultados mais consistentes com a cobertura vegetal permitiram o estabelecimento da seguinte relacão:

$$
k c b=0,36+0,012 \text { (\%cveg.) }-0,000063 \text { (\%cveg. })^{2}
$$

Esta equacáo possibilita a estimativa de kcb pela avalia-cấo do dossel vegetativo da cultura diretamente do campo. os resultados obtidos no presente trabaino E a sua concordancia com a literatura internacional demonstram a necessidade de mais investigaföes neste assun... to, para a sua generalizacáo em aplicąóes de campon 


\title{
EFFECT OF CANOPY DEVELOPMENT ON WATE CONSUMPTION AND CROP COEFFICIENT OF PEA (Pisun sat ivUm L.)
}

\author{
Auhtor: ANA CLÁUDIA ARAUSJO DE MELLO \\ Adviser: Dr. FLÁVIO BUSSMEYER ARRUDA
}

\section{SUMMARY}

\author{
This work investigates basal crop coeffi- \\ cient, kcb (JENSEN, 1976; WRIGHT, 1982), of irrigated pea \\ (pisun sativum L.) cV. Majestic to canopy development mea- \\ sured as leaf area index (LAI) and percentage ground cover \\ $(\% G C)$ \\ A field experiment was carried out with four \\ population densities (36, 50, 81 and 146 plants per $m^{2}$ ) \\ chring the winter of 1991 , on a flat, well drained dusky \\ latosol, at the Experimental Center of Campinas, Instituto \\ Agronônico, State of Sáo Paulo. Irrigation was applied \\ whenever soil water tension achieved $60 \mathrm{kPa}$, at $15 \mathrm{~cm}$, ba- \\ sed on higher population treatment of atb plants per me. \\ Real evapotranspiration (ETr) was determined \\ between irrigat ions by field water balance technique. Rew... \\ ference evapotranspiration (ETo) was est imated by modified
}


Penman equation and Class A pan evaporation.

Crop production increased with population density close to a linear relation. However, population density also increased lodging.

Water consumption, as well as kcb, were close

related to crop development and population densities. Ba-sal crop coefficient was also affected by the methodology used for ETo calculation.

The kc. values indicated by FAO CDOORENBOS \& PRUITT, 1977) for pea are higher than those found in this research, specially from flower iniciation till the end of reproduct ive phase.

Basal crop coefficient was correlated to LAI $(r=0.78)$ and to $\% 0 C(r=0.85)$. The more consistent results with ground cover, produced the following relation:

$$
k c b=0.36+0.012(\% G C)-0.000063(\% G C)^{2}
$$

That equation al lows kob est imation from canopy evaluation directly from the field.

The: present results, and its agreement with the international literature, indicates a neceseity of mow re research on this subject, for general field application. 


\section{INTRODUGAO}

o alto custo da irrigacáo exige que a aplicacăo d'água seja feita com eficiência. Desta forma, 05 custos seráo reduzidos e não haverá prejuizo da producão por excessos ols falta de água.

- Planejamento correto dos equipamentos e o adequado manejo da água na agricultura passam por um razoável conhecimento das demandas consuntivas das lavouras cultivadas em diferentes situacöes de solo e clima. A ob-... tencâo dessas informacóes deve ser feita com base em experimentacáo regional, e pelo equacionamento de um modelo que considere os principais atributos ligados ao 150 da água na producâo vegetal.

A forma mais usual de se estimar o consumo de água das culturas é a partir do consumo potencial de àgua calculado por fórmulas agrometeorológicas ou a partir de medicies feitas em tanques de evaporacáo instalados em areas com gramado. A partir destes dados, é feita uma correcáo para o estágio da cultura, utilizando-se um coeficiente de cultura $(k c)$, obtendo-se a evapotranspiraGăo másima da cultura (ETm). 
Nos ultimos anos, um grande numero de determinacöes de $k_{c}$ e evapotranspiracóes medidas ou calculadas de muitas formas têm sido realizadas em alguns locais para as principais culturas. Os resultados, apesar de sua importância, têm extensăo discutivel quanto às aplicacöes em situacöes de campo.

O ke tem sido relacionado à idade da planta em termos de dias após o plantio (DOORENBOS \& PRUITT. 1977\% DOORENBOS \& KASSAN 1.979). UMa situatä́ de cultivo pela combinacáo da fertilidade do solo, clima, doengas e demanda evaforativa, nunca se repete, especialmente, quando săo comparados diferentes anos, locais e regióes. Den-tro de uma nesma regiáo, é normal se observarem lavouras de uma mesma cultura e mesma idade cronológica, porém com orau diferenciado entre crescimento e, certamente, diferentes valores de kC E ETm.

Portanto, diante do exposto, há necessidade de se investigarem, com maior detalhe, os parâmetros uti-I izados para estimativa de consumo de água das culturas. 0 coeficiente de cultura (kc) deve ser apresentado de acordo com a nova denominaféco introduzida por WRIGHT (1982) E BURMAN Et alii (\$980), possibilitando a separagáo en con... ponentes e a sua interacto com o manejo da irrigafóo e o efeito do deficit de água. O coeficiente de cultura tam.... bém deve ser apresentado em termos relativos de planta, 
levando-se en consideragáo o porte e o desenvolvimento da cultura, ao invés de sua idade cronológica.

Com base no exposto, realizou-se o presente estudo com a ervilta, cultivar Majestic (XPC-88), en condicóes de campo, com o objetivo de: (a) relacionar o coe-.. ficiente de cultura basal (kcb) a elementos mensuráveis de planta, tais como índice de área foliar (IAF) e porcenta-gen de cobertura vegetal (\%CVeg.), para sua possivel modelagem; (b) estudar o efeito de diferentes densidades popu-.. lacionais no consumo de água e producáo final de gráos. 


\section{REUISẼO DE LITERATURA}

Dos fatores que afetam a producäo, a água é um dos itens que limita a produtividade das culturas com maior freqiếncia. Por isto, há importância de se determinar o momento exato de executar a irrigacäo, ben como a quantidade de água que deve ser reposta ao solo.

$$
\text { WIT (1958) E ARKLEY (1963) citados Por ARRU-- }
$$

DA (1987), afirmaram que para obter máximas producóes de biomassa e, possivelmente, gräos, a transpirafä́o da cultu... ra também deve ser maximizada. Náo devem ocorrer déficits hidricos que venham impor restricóes à taxa de transpiraGäo da cultura, pois se este ocorrer, especialmente no periodo critico das culturas, poderà resultar em decréscimo de producäo. Diante de tal constatacäo, fica claro que para fins de irrigafäo, o manejo ideal de água é aquel: que se aproxima da situacáo em que näo ocorrem restrifóes hidricas para a transpiragáo das plantas (ARRUDA, 1987 ).

WIT, C.T. de Transpiration and crop yields. Versiag. van Landbouwk . Onder joek, $n^{\circ} 646$. $88 \mathrm{p}$. 1958.

ARKLEY, R.J. Relationships between plant growth and transpiration. Hilgardia, 34:559-84. 1963. 
A dificuldade de se separar a transpiracão da planta da evaporacăo do solo, levou a utilizacăo dos dois termos conjugados - Evapotranspiracäo (ET). THORNTH-.. WAITE (1948) introduzi山 o termo evapotranspiracăo potencial como sendo a água evapotranspirada de uma superficie natural coberta por uma vegetacäo baixa em fase de desenvolvimento ativo e sem restricăo hidrica, sendo funcăo somente das condicóes climáticas prevalescentes.

DOORENBOS \& PRUITT ( 1977 ) E DOORENBOS \& KAS-SAN (1979) reviram os conceitos e terminologia de consumo de águ, e redefiniram a evapotranspiracăo potencial de THORNTHWAITE $(1948)$, como sendo a Evapotranspiracáo que ocorre em uma superficie totalmente vegetada com grama, com 8 a $15 \mathrm{~cm}$ de altura, em fase de desenvolvimento ativo, estando o solo com teor de umidade próximo ao da capacida-de de campo: a ela denominaram evapotranspiracáo de referencia (ETo). A superficie vegetada por uma cultura saudá-.vel qualquer, em condifóes de nenhuma restrifäo de água em qualquer estágio de desenvolvimento, a perda d'água que ocorre é dita evapotranspiracäo máxima (ETm). Para os mesmos autores, a evapotranspiracáo real (ETr) refere-se à perda d'água que ocorre em uma cultura qualquer, com ou sem restrifăo de água, em qualquer estágio de desenvolvi-... mento

JENSEN (1969) sugeriu a adofäo da al fafa com 30 a 50 cm de alura, como cultura de referência para a 
determinacăo da evapotranspiracăo de referência, por apresentar caracteristicas aerodinâmicas e anatômicas semelhantes às principais culturas. Porém, o uso dessa cultura como referência fica limitada a sua regiâo ecológica de cultivo. PIRES et alii (1988) sugerem a possibilidade do uso do rami como cultura de referencia nas regiốs tropicais. Certamente, a medicâo da evapotranspiracăo ocorrida em gramado tem uma amplitude maior de utilizacão do que outras culturas.

TANNER (1967) E DOORENBOS \& PRUTTT (1977), relatam vários métodos para determinafáo ous estimativa da evapotranspiracăo. BURMAN et alii (1980) classificam-nos en dois grandes grupos: 1) métodos em que a evapotranspi-racáo pode ser determinada através de medidas diretas: ou seja, métodos do balango d’água no solo, que incluem os: lisimetros pesáveis e os nấo pesáveis, método do inflowoutflow (entrada-saída) e do controle de umidade no solo: E 2) os métodos indiretos ou de est imativas, que determinam a evapotranspiracáo através de fórmulas empiricas que requerem medicöes meteorológicas, dentre estes, cita-se: método de Penman, Penman modificado pela faO, Jensen -..Haise, Blaney - Criddle, tanque Classe A.

SEDIYAMA (\$987) relata a existência de vá-rios métodos de estimativa de evapotranspiracăo, desde modelos mito simples até os baseados em modelos físicose fisiológicos. A escolha do método deve ser baseada, prin- 
cipalmente, no tipo de dado climatológico disponivel e na precisão requerida na determinacäo das necessidades hidricas dos cultivos. No entanto. BURMan et alii (1980) consideram que as equacóes para estimativa de evapotranspiracáo que apresentam melhor performance säo aquelas que requerem dados diários de radiacăo, temperatura, pressäo de vapor e vento. Existe um conscenso em nosso meio de que a equacäo de Penman é a que melhor se adapta para estimativa da evapotranspiracăo de referência.

A quantidade de água evapotranspirada depende, principalmente, de fatores da planta, do solo e do clima, sendo este último fator predominante sobre os demais quando näo há limitacăo de água no solo. A demanda consuntiva de uma cultura pode ser definida como a soma da água evapotranspirada, mais a parte retida pelo tecido ve-. getal durante o seu crescimento. Como a segunda parte é muito pequena em relacăo à primeira, pode-se considerar a demanda consuntiva igual à Evapotranspiracăo (BERNARDo. 1982). Segundo JENSEN (1969). este total de água retido pelos tecidos das plantas. em geral. equivale a menos de $1 \%$ do total evapotranspirado durante o seu ciclo de cres-c. imento.

JENSEN (1969) E PRUTTT Et alii (1972) constataram que para uma mesma cultura, podem-se esperar diferencas no consumo de água quando cultivada em diferentes regiöes, condicöes climáticas épocas de plantio, fato 
Este atribuido aos parâmetros meteorológicos controladores da evapotranspiracăo 〈radiacăo solar, vento, umidade relativa e temperatura).

As plantas, desde a semeadura até a colheita, passam por diferentes estágios, em que as necessidades hidricas também săo distintas. O aumento do uso das irrigacóes, assim como o alto custo envolvido em tal prática, tem aumentado a procura por informacóes a respeito dos requer imentos de água em todos os estágios de desenvolvimen-to das culturas. Uma maneira de se quantificar essas necessidades é a determinacăo da evapotranspiracăo de refe.rência (ETó, que por intermédio de um coeficiente apropriado para os vários estágios de desenvolvimento, denominado coeficiente de cultura (ke), pode-se estimar a evapotranspiracăo máima da cultura (ETm), pela seguinte relaGล̃O (DOORENBOS \& PRUITT, 1977$):$

$$
\begin{gathered}
\text { ETm }=k c . \text { ETo } \\
\text { O coeficiente de cultura (kc) tem sido obje- }
\end{gathered}
$$
to de intensa pesquisa na determinacäo do consumo de água das plantas, por estagio de desenvolvimento.

Ut il izando-se de um lisimetro de nivel constante, CuRY (\$985) determinow os coeficientes de cultura para o repolho (Brassica oleracea var. capitata L) em reIacăo à evapotranspiracăo de referência (ETo) est imada pelos métodos de Penman, Penman modificado, Tanque Classe $A$, Radiacăo Solar. Thornthwaite, Thornthwaite modificado, Li -.. 
nacre. Essa autora comparou os valores de kc com os propostos pela FAO (DOOREENBOS \& KASSAN, 1979). Concluiu haver una grande variabilidade entre os mesmos, e que os valores do período do inverno foram sempre maiores que os de veräo, sugerindo, pois, näo se utilizar um coeficiente unico anual

ASSIS (1978) correlacionou os valores de nedida de evapotranspiracäo de referência através de lisime.-. tros de nivel constante com os valores estimados através o Tanque Classe A e Penman. Concluiuque, para a regiáo de Piracicaba, a relacáo entre os valores medidos pelo lisimetro (M) e os estimados (E) pela equacáo de perman. e da forma: ETOE $=0,81 E$ Tom: diferenca esta atribuida à advectáo local näo computada por aquela equacáo. Observou ainda, haver uma correlacáo altamente significativa entre os valores de evapotranspirafäo medidos na grama est imados pelo Tanque Classe A.

Com o intuito de avaliar a evapotranspiracáo máxima dos vários estágios de desenvolvimento da cana-de-. aficar no ciclo da la soca, em Piracicaba, PERES (1988), ut il izando-se de um equipamento semelhante aos ut ilizados POr ASSIS (1978) E CURY (1985), concluiu näo haver diferenca significativa ao nivel de $1 \%$ de probabilidade entre os coeficientes de cultura determinados pelos métodos de Penman e Tanque Classe A* porém ambos diferiram estatisti 
camente do coeficiente de cultura determinado pelo método de Thornthwaite.

PAVANI (1985) desenvolveI In Experimento cujo objetivo foi avaliar a produtividade do feijáo comum (Phaseolus vulgaris, L.), sob três niveis de evapotranspiracáo. De acordo com os resultados obtidos, as principais conclusöes foram:

- O maior consumo d'água da cultura se verificou no periodo de floracáo enchimento dos gräos, em que os valo... res decendiais do coeficiente de cultura (kc) foram os mais elevados e dependentes da variacáo do indice de área foliar (IAF) da cultura;

- Os valores decendiais de kc estimados foram sempre superiores aos do $k_{\text {ce }}$ propostos pela FAO (1979), no periodo entre o $3^{\circ}$ e o go decêndio da cultura.

Ut ilizando-se de uma bateria de três lisimetros de nivel freatico constante, COSTA (1989) determinou os valores de coeficiente de cultura (kc) por fase de de-... senvolvimento vegetativo da cultura do trigo (Triticum aestivum, L), pelos métodos de Penman. Penman modificado, Tanque Classe A. Radiacáo Solar e Thornthwate. Esse autor concluiu que os valores de $k_{c}$ determinados pelos métodos de Penman e penman modificado foram os que apresentaram maior concordância com os valores recomendados pela faO (DOORENBOS \& KASSAN, 1979). 
VOLPE (1986) E MINCHIO \& VOLPE (1987) detErminaram os consumos de água e os coeficientes de cultura Para diferentes cultivares de ervilha (Pisum sativum $L_{*}$ ), através de lisimetros de drenagem profunda, e estimando a evapotranspiracăo de referência através do método do tanque Classe A. Observaram que os valores de kc obtidos para os diferentes periodos de crescimento dos cultivares, desde a semeadura até a colheita de grä́os secos, foram mais elevados que aqueles sugeridos pela FAO CDOORENBOS \& KASSAN, 1979).

Esta grande variabilidade entre os valores obtidos de $k_{C}$, mostram, dentre outros fatores, a grande: discrepância existente entre as vărias fórmulas para est imativa da ETo.

HANKS \& ASHCROFT (1980) teCERAM comEntáriOS a respeito dos valores de $k_{C}$ e enfatizaram a variacáo deste coeficiente em funcäo da latitude. Esse fato, a rigor. inviabiliza a utilizacéo de valores de ke universais, como POr ExEMPIO os da FAO \{DOORENBOS \& PRUITT, 1977: DOORENBOS \& KASSAN, 1979).

Segundo HILLEL (2990), kC é maior em clima quente, com vento seco, do que em clima ameno, calmo : Limido. ke varia largamente entre as culturas, devido às diferengas em altura das plantas, "rugosidade" da superficie evaporante, reflectividade, graude cobertura e resis... tencia do dossel vegetativo à transpiracáo. 
SAMIS et alii (1985) para as condicöes do Novo Mérico (EUA) relacionaram o coeficiente de cultura (kc) da alfafa (ETmedido/ETpenman) com graus-dias de cres-cimento (G), acumulados pela soma da temperatura média diária menos a temperatura basal da cultura (50C). Eles obtiveram a seguinte relacáo, estatisticanente significativa:

$$
k c=0.405+1.11 .10^{-3} \mathrm{G}-4.25 .10^{-7} \mathrm{G}^{2}+3.56 .10^{-1} \mathrm{G}^{3}
$$

Vários PESquisadorES (WRIGHT, 1982: BURMAN et alii, 1980 ) têm apresentado um novo conceito de $k c$, que incorpora o ajuste devido ao molnamento da superficie do solo na época de irrigacáo ou chuva e o efeito do déficit hidrico. Sua representacäo é a seguinte:

$$
k c=k_{c b}=k_{c s}+k s
$$

en que kcbé o valor basal do coeficiente de cultura quan-do o suprimento d'água é adequado, mas a superfície do so-10 é secá kcs é o fator cultura-solo e expressa o efeito dá disponibilidade de águá e ks é o fator que considera a evaporacăo d’água da superficie do solo.

$$
\text { JENSEN et alii (1971) propuseram a seguinte }
$$

relacáo para o valor de kes (cultura-solo):

$$
k c 5=\frac{\ln (A D i+1\rangle}{\ln 101}
$$

em que $A D_{i} e ́$ a água disponivel existente no solo $(\%)$, sendo $100 \%$ para a $C . C . E$ q $0 \%$ quando no PMP. Esta funcäo indica pequena reducăo na transpiracáo até que a água disponivel esteja abaixo de $75 \%$ e também năo há grande reducăo até 
que Pelo menos $50 \%$ da $A D$ seja consumida. O kcs representa - efeito direto do stress hídrico, principalmente na abertura dos estômatos"

$$
\text { - fator de evaporacáo do solo (ks) pode ser }
$$

Est imado por:

$$
k s=\left(1-k(b) N^{-t}\right.
$$

em que $t$ é o número de dias desde a irrigacăo ou chuva, $N$ Eum fator que relaciona a textura do solo; sendo 1, O para argila: 1,5 para franco-argiloso:2,0 a 2,5 para franco (barro) e 3,0 a 3,5 para areia. Logo após a irrigacáo (t = $0)$, ks é complementar a kcb, $e$ o kc= $=1.0$. Com o passar do tempoks, torna-se desprezivel.

Utilizando-se deste novo conceito para determinacăo do coeficiente de cultura, WRIGHT (1982) determinou-os por estágio de desenvolvimento para as culturas irrigadas de alfafa, batata, beterraba, ervilha, milho e cereais de inverno e primavera, para regiöes do Nordeste do acifico. Oreferido autor afirma que os novos coefi-. cientes de cultura ( $k c)$ determinados, quando combinados, com estimativas de evapotranspiracăo de referência di rias, permitem maior exatidáo nas estimativas de evapotranspiracáo real das culturas (ETr), assim como no planejamento da irrigacäo.

As plantas influenciam a evapotranspiracão através da área foliar e cobertura vegetal que elas produzen: altura e resistência oferecida ao flu»o d'água através da planta para a atmosfera (BLAD, 1983). 
Vários autores, dentre eles PETRAsOUIC (1973), WRIGHT (1982) E PAVANI (1985) notaram uma estreita relacăo entre kc e a área foliar ao longo do ciclo da cultura. Por exemplo, BRUN et ali i (1972) mostraram que a fracáo do total da evapotranspiracão relativa à transpira-Gáo esteve estreitamente relacionada ao indice de área foliar (IAF): para $1 \mathrm{~m}$ IAF de 2,0 , a transpiracáo $\left(T_{p}\right.$ ) foi de aproximadamente $50 \%$ do total evapotranspirado, enquanto que para um IAF de 5,0 , a transpiracáo $\left(T_{p}\right)$ foi equivalente a $95 \%$ do total evapotranspirado. Tendências similares for am encontradas por FERERES \& UILLALOBOS (1990) para as culturas de algodáo, girassol e milho.

L.UEBS et alii (1975) E MOURA (1990) observaram que com adequada disponibilidade de água, respectiva-.. mente, para as culturas da cevada (Hordeum vulgare L.) e do milho (Zea mays L.), a evapotranspiracäo esteve rela... cionada à quantidade de cobertura vegetal.

GOLDBERG et alii (1967) mostraram uma boa aprokimaczio dos valores de $\mathrm{ke}$ com a porcentagem de cober-. tura vegetal (\%o. Veg.) para a cultura do amendoim. o valor de ke variou ao longo do ciclo da cultura da seguinte forma: 5010 nu até $20 \%$ de cobertura vegetal o ke manteve-se estavel en torno de 0,3 , a partir de entäo, houve um crescimento linear entre kc e a \% c.Veg ate que, para $100 \%$ de cobertura vegetal o valor de kC atingiu $\boldsymbol{l}_{\text {. }}$ 
HEILMAN Et alii (1982) realizaram um estudo com a cultura da alfafa (Medicago sativa L.) para obtencáo do ke sob quatro niveis de irrigacäo. Observaram uma estreita relacăo $(r=0,815)$ entre o ke e porcentagem de cobertura vegetal em todos os tratamentos.

TAN \& FULTON (1980) realizando estudos para determinacăo de ke para as culturas de batata, milho e tomate industrial, também observaram relacöes de dependência entre o coeficiente de cultura e a porcentagem de cobertura vegetal.

Levando-se em consideracăo os componentes de kc, e assumindo uma estreita relacăo dekc e kcb com a "C. Veg*: ARRUDA (1989) propóe critérios práticos para determinacäo do coeficiente de cultura no Estado de Săo Pau10 para 150 em irigacăo sem restricäo hidrica. Tais parâ-.metros sấo assim recomendados: no dia da irrigafáo, independente da porcentagem de cobertura vegetal, o valor que o ko assume é sempre 1 , 0 após a irrigafáo, os valores de ke irăo variar de acordo com a porcentagem de cobertura vegetal da seguinte forma: no estágio inicial da cultura, quando o solo encontra-se em grande parte descoberto $\left\langle \% V_{e g}\langle 30 \%\right.$ o $k C$ assume um valor $0,3 \%$ en seguida, quando o solo encontra-se parcialmente vegetado, ou seja, $30 \%<\%$ C. Veg.<100\%, o valor do ke será dado pela relacâo $k c=\%$ C. Veg $/ 100$. Quando o solo encontra-se totalmente: vegetado, $\left(\% C \cdot V_{e g}=100 \%\right)$ o valor de ke será $1,0$. 
ESPINOZA (1979) realizou um Estudo em que avalious oefeito da densidade de plantio $(20,40,60$ e 80 mil plantas por hectare) sobre a evapotranspiracăo da cultura do milho irrigado. Ele concluis que a evapotranspiraGăo aumentou com a densidade de plantio. Esse fato foi explicado pela estreita relacão $(r=0.99)$ entre a evapotranspiracăo (ET) e o indice de área foliar (IAF), determinados na fase de florescimento da cultura em todos os trat amentos.

ASSIS Et alii (1991) mediram a Evapotranspiraço máxima (ETm) do sorgo (Sorghum bicolor) através de um evapotranspirômeto de nivel de água constante. Observa-ram que a taxa de variacăo da ETm durante o ciclo da cultura, seguiı o mesmo padräo do indice de área foliar (IAF), com uma equacä́o de regressáo da seguinte forma: ETm $=3.0+0,22 I A F(r=0.996)$. Segundo os autores, este fato, se confirmado, representaria uma grande vantagem na avaliacăo da ETm de culturas. No entanto, ao se faser uma análise da equacăo de regressä́ proposta por estes autores. percebe-se que ao relacionar a ETm apenas ao IAF os autores estäo ocultando o efeito da demanda atmosférica expresso através da ETor o que trará como consequências Eros de estimativas da ETm para diferentes anos, principalmente en regióes que apresentem oscilacóes climáticas. Em face do exposto, parece ser mais conveniente relacionar - IAF ao coeficiente de cultura $(k c)$, visto que ambos são funcăo principalmente da planta. 


\title{
3. MATER IAIS E MÉTODOS
}

\subsection{Local}

\begin{abstract}
- presente estudo foi realizado no Centro Experimental de Campinas do Instituto Agronômico do Estado de Sä́ Paulo (IAC), cujas coordenadas geográficas săo 22053's de latitude, 47004 W de longitude, e altitude de 706 metros.
\end{abstract}

\subsection{Clima}

o clima regional é do tipo "CWA", conforne classificacăo de koppen, definido como inverno seco, tem.peratura do mês mais quente superior a $22^{\circ} \mathrm{C}$ e do mês mais frio inferior a $180 \mathrm{C}$. Os valores normais de precipitacáo anual săo de $1365 \mathrm{~mm}$, evapotranspiracăo potencial anual de $955 \mathrm{~mm}$, com excedente hidrico de $433 \mathrm{~mm}$ e deficiencia hidrica de $23 \mathrm{~mm}$, obtidos pelo balanco hidrico de THORNTHWAI... TE A MATTER $(1955)$, considerando-se um armazenamento de sasmm de água no solo, conforme dados fornecidos pela se.C.äo de Climatologia Agricola do IAC. 
Os dados meteorológicos usados neste traba-Iho, relativos ao ciclo da cultura, estäo apresentados nas Tabelas 1 a 3 do Apêndice. Eles for am obtidos no Posto Me... teorológico instalado no CEC, sob condicótes padronizadas fornecidos pela Secáo de Climatologia Agricola do IAC.

\subsection{0}

$$
\text { O solo local foi classificado como latossolo }
$$

rono, série taquaral, de acordo com a Secáo de Pedologia do IAC.

\subsubsection{Textura e Densidade}

A textura do solo foi determinada através da análise granulométrica, pelo método da pipeta na quantifi.-. cacăo do teor de argila: tamisamento para a separacáo da frafáo areia e, por diferenca, o teor de silte, após dis... persäo da terra fina seca ao ar (TFSA) com hidrókido de sódio e agitacăo mecânica (CAMARGo et alii, 1986).

A densidade global do solo, a cada 20 cm até a profundidade de $100 \mathrm{~cm}$, foi determinada utilizando-se amostras indeformadas coletadas em anéis volumétricos de $1000 \mathrm{~m}^{3}$. Para as mesmas profundidades, através do metodo do picnômetro,foi estabelecida a densidade de particulas (CAMARGO et ali i, 1986). Os resultados da análise granulomé- 


\begin{abstract}
étrica, densidade global de particulas, encontram-se na Tabela 1 e for an determinados pela Secáo de Pedologia do IAC.
\end{abstract}

Tabela 1 - Resultados da análise fisica, do latossolo roxo, série taquaral, Campinas, SP.

\begin{tabular}{|c|c|c|c|c|c|c|}
\hline \multirow[b]{2}{*}{ Prof. } & \multicolumn{2}{|c|}{ Areia } & \multirow[b]{2}{*}{ Silte } & \multirow[b]{2}{*}{ Argila } & \multicolumn{2}{|c|}{ Densidade } \\
\hline & Grossa & Fina & & & Global & Partícula \\
\hline$c \mathrm{~m}$ & $-\cdots$ & ----9 & $-\cdots$ & ----- & ------9 & $\mathrm{~cm}^{-3}$ \\
\hline $\begin{array}{r}0-2 \theta \\
2 \theta-4 \theta\end{array}$ & $\begin{array}{l}16,7 \\
13,2\end{array}$ & $\begin{array}{l}17,1 \\
14,3\end{array}$ & $\begin{array}{l}5,0 \\
5,0\end{array}$ & $\begin{array}{l}61,2 \\
67,5\end{array}$ & $\begin{array}{l}1,22 \\
1,13\end{array}$ & $\begin{array}{l}2,73 \\
2,76\end{array}$ \\
\hline
\end{tabular}

3.3.2. Curva de retencăo da água

A curva característica de água do solo foi determinada mediante extratores de placas porosas (RICHARDS, 1956). Para tal, foram coletadas amostras indefor-.. madas de 5010 através de anéis volumétricos de $100 \mathrm{~cm}^{3}$ pa-.ra profundidades de 25, 35, 45, 55 e $65 \mathrm{~cm}$; as amostras para a camada superficial de $0-20 \mathrm{~cm}$ foram preparadas em laboratório, passando-as em peneiras de malha de $2 \mathrm{~mm}$.

As anostras foram submetidas a pressöes que: variaram de 0,1 a 15,0 atn. na panela $e$ na câmara de $R i-$ chards, com cinco repeticöes para cada profundidade: de... terminando-se por desorgáo a relacáo entre unidade do solo e o potencial matricial para cada profundidade de $8-70 \mathrm{~cm}$. Aos resultados obtidos, por canada de solo, foran ajusta- 
das curvas do tipo propostas por VAN GENUTCHEN (1980), de acordo com programa computacional especifico desenvolvido por DOURADO NETO et alii (1990), cuja Equacáo ajustada é a seguinte:

$$
\theta=\theta r+\frac{\theta_{0}+\theta r}{\left[1+(\alpha \cdot h) n_{]}\right.}
$$

sendo $\theta$ a umidade volumétrica do solo num instante qualquer $\left(\mathrm{cm}^{3} \cdot \mathrm{cm}^{-3}\right)$ correspondente ao módulo do potencial h (cm de água): 00 er, säo respectivamente, as umidades volumétricas do solo na saturacăo, Ea residual correspondente ao potencial de $15000 \mathrm{~cm}$ de água, ambas em $\mathrm{cm}^{3} \cdot \mathrm{cm}^{-3}$, E $\alpha, m, n$ săo parâmetros do solo.

Os parâmetros $\alpha, m, n, \theta 0 \in$ or da equacăo (1), para as diferentes profundidades do solo, encontram... se na Tabela 2.

Tabela 2 - Parânetros da curva de retençóo de água solo, para seis profundidades do latossolo roxo, se-.. rie taquaral, segundo o modelo de Van Genuchten $(\$ 980)$.

\begin{tabular}{|c|c|c|c|c|c|}
\hline \multicolumn{6}{|c|}{ Par âmetros } \\
\hline Profundidade & $\alpha$ & $m$ & $n$ & $\theta 0$ & $\theta r$ \\
\hline$c m$ & $c m$ : água & & & $--c n^{3}$ & $=m^{-3}$ \\
\hline$\theta-2 \theta$ & 0,011493 & 0,404447 & 1,679112 & 0,553 & 0,223 \\
\hline $28 \cdots 30$ & 0,095555 & 0,285280 & 1,398992 & 0,520 & 0.297 \\
\hline $30-40$ & 0,124962 & 0,299056 & 1.426647 & 0,561 & 0,265 \\
\hline $48-50$ & 0.116450 & 0,300133 & 1.428843 & 0,565 & $0.25 \%$ \\
\hline $50-60$ & 0,086720 & 0,307745 & 1,444555 & 0,556 & 0,259 \\
\hline $60-78$ & 0.084016 & 0,342480 & 1,528865 & 0,579 & 0.258 \\
\hline
\end{tabular}




\subsubsection{Condutividade hidráulica}

o valor da condutividade hidráulica do solo $(K \theta)$, Em funcâo da sua umidade $(\theta)$ foi determinada através da equacăo desenvolvida por VAN GENUCHTEN (1980). Este autor relaciona a condutividade hidráulica relativa, Kr. à curva característica de água no solo, baseado em um modelo desenvolvido por MUALEN (1976). Para camadas individuais de solo, a condutividade hidráulica relativa, Kr," en fun-... Gäo do sels contelido de água, é estimada por:

$$
K r=w^{1 / 2} \cdot\left[1-\left(1-w^{1 / n}\right)^{m}\right]^{2}
$$

sendo W uma unidade adnensional, dada pela equacăon

$$
\omega=\frac{\theta-\theta_{r}}{\theta_{0}-\theta_{r}}
$$

en que os parâmetros $m, n, \theta, \theta r$ e $\theta 0$ săo os mesmos já definidos na equacão i da curva caracteristica (Tabela 2).

Para o cálculo da condutividade hidráulica relativa do solo en funcáo de sua umidade, Kr, basta obter o valor de w correspondente ao de $\theta$ desejado pela eq. (3) e aplicar na eg.(2). A condutividade hidráulica do solo em functio de $\theta, K(\theta)$, é finalmente obtida, multiplicando-se os valores da $e q .(2)$. condutividade hidráulica relativa, Kr. pela condutividade hidráulica saturada do solo, Ko.

o valor da condutividade hidráulica saturada do solo, Ko, determinada através do teste de infiltracio de água no solo no local do experimento, é de 3 , $60 \mathrm{~cm}^{-4}$. 


\subsection{Cultura}

O cultivar de ervilha (Pisum sativum L.) selecionado para o presente estudo foi o Majestic (XPC-88), de ciclo curto, por tratar-se de uma cultura de inverno bastante resistente às baixas temperaturas (INSTITUTO AGRONOKMCO, 1987).

\subsection{Delineamento experimental}

o delineamento experimental foi o de blocos ao acaso com quatro tratamentos e cinco repeticöes. Os tratamentos referiam-se a diferentes espacamentos entre linhas deplantio $(15,30,45 \in 60 \mathrm{~cm})$, o que correspondiani, respectivamente, às populacóes de $146: 81: 50$ e 36 plantas por metro quadrado, para induzir diferencas em area foliar e cobertura vegetal entre as parcelas.

As parcelas, em número de 20 , tinhan as dimensóes de 8 por 5 metros, e eram circundadas por uma área tampäo vegetada com ervilha, perfazendo um total de 1 ha.

3.6. Instalacão e conducăo do experimento

\footnotetext{
Forani realizadas duas gradagens e uma arafäo no solo e logo após, foi passado um sulcador com hastes distanciadas de $60 \mathrm{~cm}$.
} 
A semeadura foi realizada manualmente en 10 de jultio de 1991, em sulcos feitos com enxada na direfäo N-S, com aproximadamente $5 \mathrm{~cm}$ de profundidade. Foram $5 e^{-}$ meadas 30 sementes por metro linear o que corresponde, em média, a 20 plantas viáveis por metro, en todos os tratamentos. A emergência ocorreu uma semana após o plantio.

Foi realizada uma adubacăo à lanco nos sulcos, na semeadura, com $1000 \mathrm{~kg} / \mathrm{ha}$ da fórmula 4-14-8. Trinta dias após a germinacăo realizou-se uma adubacăo de cobertura na área com nitrocálcio na dosagem de $600 \mathrm{~kg} / \mathrm{ha}$.

Foram feitas duas capinas manuais, aos 15 e aos 33 dias após a semeadura, para controle das ervas daninhas. Durante o experimento, foram necessárias duas aplicacóes de inseticidas, sendo que a primeira delas foi realizada para combate do tripes com uso do Folidol, e a segunda para combate do pulgä́o com uso de Phosdrim. Estas aplicacốs foram feitas aos 23 e 50 dias após o plantio.

\subsection{Balanco Hidrico}

$$
\text { o consumo de água da cultura foi avaliado }
$$

através do balanco de massas em um volume de controle do solo equivalente aos primeiros $40 \mathrm{~cm}$ de profundidade.

A equacáo do balanco hidrico de uma camada de solo de profundidade $z$ num intervalo de tempo $t_{2}-t_{1}$ $\Leftrightarrow$ descrita da seguinte forma (REICHARDT, 1985)" 


$$
\int_{t_{1}}^{t_{2}}\left(p+i+-d_{s}-q_{e}+-q_{z}\right) \cdot d t=\int_{0}^{2} \int_{t_{1}}^{t_{2}}\left(-\frac{\partial \theta}{\partial t}\right) d t \cdot d z
$$

em que $p, i, d_{s}, q_{E}$ e $q_{z}$ representam, respectivamente, $0 s$ fluxos de precipitacăo, irrigacăo, escoamento superficial, evapotranspiracáo e drenagem profunda ou ascensáo capilar (mn.dia-1); e $\theta$ representa a unidade volunétrica do solo $\left(c m^{3} \cdot\left(m^{-3}\right)\right.$. A primeira parte da equacăo representa os fluxos de entrada e saida. O segundo membro da equacáo corresponde à variacăo no armazenamento da água dentro do volume de controle, num dado periodo de tempo.

A equacáo 4 pode ser escrita de maneira mais simplificada, integrando-a com relacăo ao tempo $e$ à prom fundidade:

$$
P+I+-R+-D S-E T r=+-\Delta A
$$

em que a representa a variagấo (em mm nos conteúdos de água no solo, no volune de controle no periodo considerado*

o deflúvio superficial näo foi considerado na análise dos componentes do balango hidrico, devido à pouca declividade do terreno (menos de $2 \%$ ), alta velocidade de infiltracáo do 5010 (ko $=36 \mathrm{~mm}^{-1}$, associados às baixas precipitacóes ocorridas e alto controle das irrigaGóes durante o ensaio. Assim. a expressäo utilizada para a determinacăo da evapotranspiracăo, foi:

$$
E T r=P+I+-D S+-\Delta A
$$


Na avaliacăo dos componenteg do balanco hidrico, a profundidade de $40 \mathrm{~cm}$ considerada para o volume de controle esteve correlacionada com a profundidade efetiva do sistema radicular da cultura, que no caso da ervilha, segundo PIRES \& WUTKEl, limita-se aOs primeiros $30 \mathrm{~cm}$.

3.7.1. Variacăo no armazenamento de água no solo

A variacăo no armazenamento de água no solo foi estimada a partir de perfis consecutivos de umidade do solo, obtidos entre duas irrigacóes.

Para determinacáo de $\theta$, foi empregado o método gravimétrico, através de amostras coletadas com trado nas profundidades de $0-10,10-20,20-30$ e $30-40 \mathrm{~cm}$, com 5 repeticöes por tratamento. Após a coleta, as amostras eram acondicionadas em latas de alumínio e secas em estufas à $1050 \mathrm{C}$ por 40 horas. Para a estimativa do armazenamento de água no $5010(A)$, foi empregada a fórmula:

$$
A=\bar{\theta} \cdot z
$$

Em que $\bar{\theta}$ é a umidade média do perfil do solo (cm $\left.{ }^{3} \mathrm{~cm}^{3}{ }^{3}\right)$ até a profundidade $Z$ igual a $40 \mathrm{~cm}$.

A variacăo nesse armazenamento ( $\Delta A$ ) num $p \in \cdots$ riodo ta- tif foi determinada por:

$$
\Delta A_{1}=A_{2}-A_{1}
$$

1. Pires, R.C.M. \& WUTKE,E.B. (IAC, Instituto Agronômico de Campinas) Comunicacáo pessoal, 1991. 
Em que $A_{1} \in A_{2}$ säo os armazenamentos de água no 5010 (mm) nos tempos considerados.

\subsubsection{Precipitacä́ pluvial e irrigacão}

A precipitacăo pluvial foi obtida com dados diários observados em un pluviômetro situado próximo à área cultivada.

As irrigacóes foram realizadas por meio de aspersores instalados na érea, no espacamento de la por 18m, cujas vazóes eram medidas através de um hidrômetro instalado na linha mestra de aducäo. O controle das irrigacóes foi feito por meio de tensiómetros e amostragens gravimetricas do solo, E iniciadas quando a tensäo de água no 5010 na zona das raízes ( $\{5 c m$ ) at ingia $0.06 \mathrm{MPa}$.

As lâminas aplicadas foram suficientes para elevar a unidade do solo à capacidade de campo. Nas parcelas especificas para o balanco hidrico, as lâminas de irrigacáo foram medidas através de pluviômetros instalados nas mesmas "

\subsubsection{Drenagen profunda}

os flumos verticais de água no solo na profundidade limite (Z) do volume de controle, foram estima dos, diariamente, a partir da equacäo de Darcy: 


$$
q z=-K(\theta)-\frac{\partial}{\partial z}
$$

en que $q_{z}$ é o fluxo vertical, ascendente ou descendente. en $c m^{3} . c m^{-2} . d i a^{-1} ; \quad k(\theta)$ é a condutividade hidráulica en

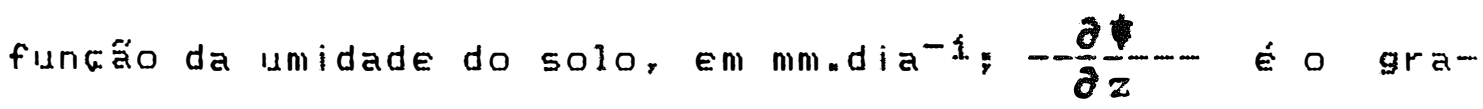
diente de potencial hidráulico en $c m=c m^{-1}$.

o potencial matricial e a condutividade hidráulica de cada camada de solo foram calculados a partir da medicâo da umidade do solo, da curva característica e da relac年o $K\langle\theta\rangle$.

Diariamente, determinou-se un valor médio da condut ividade hidráulica, da seguinte forma:

$$
\begin{gathered}
K(\theta)=-K(\theta 1)+K(\theta 2) \\
A \text { drenagem total em determinado periodo foi }
\end{gathered}
$$

calculada por:

$$
D S=q_{z} \cdot \Delta t
$$

em que dS é a drenagem total no periodo $(m m): q a=0$ fluxo de água na profundidade $z=40 \mathrm{~cm} ; E \Delta t$, o intervalo em dias entre duas anostragens.

\subsubsection{Evapotranspiracão real (ETr)}

$$
\text { A Evapotranspiragåo real da cuItura (ETr) }
$$

dos tratamentos submetidos ao balanco hidrico de campo, foi calculada a partir da resoluga de cada um dos elementos da Eq. (6): sendo que ETr foi a incógnita en determinaธุลัว. 


\subsection{Evapotranspiracấo de referência (ETo)}

Para determinacăo da evapotranspiracão de referência (mm.dia-1) foram utilizados dados meteorológicos relacionados aos seguintes métodos:

\subsubsection{Método do Tanque Classe A (EToA)}

A evapotranspiracäo de referência medida através do tanque classe $A\left(E T_{0} A\right)$, em mm.diali, foi estimada pelos resultados da evaporacăo do Tanque Classe fi (Etanque), pela relagão (DOORENBOS \& KASSAN, 1979):

$$
E T o A=E_{t a n q u e} \cdot k p
$$

em que Etanque é a evaporacăo do Tanque classe A cmin. dia-1; representada pelo valor médio diário do periodo considerado, $k_{p}$ é o coeficiente do tanque que foi determi... nado a partir do valor da velocidade média do vento, da umidade relativa do ar, e das condicöes de exposicäo do tanque. O valor do kp foi calculado diariamente durante todo o cicio da cultura, segundo DoORENBOS \& PRUTTT (1977).

3.8.2. Método de Pennan Modificado (EToPn*) (UILLA NOUA \& OMETTO, 1981)

Este método é uma versäo do método de Penman (1948), modificado e adaptado para o Estado de Säo Paulo 
por UILLA NOVA \& OMETTO (\$981). Esta versäo é indicada para áreas em que se dispöe de dados de temperatura média diária (T) em ${ }^{\circ} \mathrm{C}$, duracăo média real de insolacăo (n) em h.dia $a^{-1}$ e evaporacăo diária medida em evaporimetro de Piché ( $P i)$.

A Evapotranspiracáo de referência medida através deste método (EToPn*), representa o valor médio em mm/dia do período considerado, é obtida através da sem guinte relacăo:

$$
\text { EToPn }{ }^{*}=-\frac{\Delta}{\boldsymbol{\Delta}}+\frac{\boldsymbol{\Delta}}{\boldsymbol{\gamma}} \mathrm{H}+0,28 \mathrm{Pi}
$$

Os coeficientes de ajuste para o termo energético $\left(-\frac{\Delta}{\Delta}+\frac{\Delta}{y}\right)$, säo valores expressos em funcăo da temperatura em graus centigrados: sấo apresentados em forma de tabelas em OMETTO (1981).

O termo H significa a energia liquida disponivel sobre superficies vegetadas. Nesta simplificacáo do método de Penman ( $\{948$ ), os pesquisadores indicam duas equacóes para estimativa do balanco de energia, sendo uma para o periodo primavera - veráo e outra para o outonol inverno. Para o presente estudo, conduzido no período de Julho a setembro, adotou-se a equacáo utilizada para determinacäo do termo energét ico, correspondente ao periodo outono - inverno.

$$
\text { Hoi }=Q 0[0.17+0.11-\cdots--]
$$


Sendo Qo a radiaçón solar global no topo da atmosfera em mm/dia, No número máximo de horas de brilho solar e n o número de horas de sol ocorrido naquele dia.

3.9. Coeficiente de cultura

o coeficiente de cultura kc é obtido pela

relacio:

$$
k c=\frac{\text { ETr }}{\text { ETo }}
$$

Em que ETr é a evapotranspiracăo real medida no tratamento de irrigacáo e ETo a evapotranspiracăo de referência, que depende exclusivamente das condicốs climáticas.

Vários métodos poden ser adotados na sua de-... terminacăo, dependendo da forma de obtencăo da ETo. No presente estudo, eles for am estimados, indiretamente, pela evaporacáo do tanque classe A e método de Penmam Modificado, e diretamente, através do balanco de água no solo (ETr).

3.10. Cobertura vegetal

A cobertura vegetal foi determinada utilizando-se o método da corda descrito por SLONEKER \& MOLDE-NHAUER (1983). Para tanto, utilizou-se uma corda com 100 pontos assinalados a cada $10 \mathrm{~cm}$ ao longo do seu compri... mento, a qual era estendida no topo das folhagens formando 
$u m$ ângulo de $45^{\circ}$ em relacấo às linhas de plantio: o numero de pontos cuja projecáo horizontal coincidia com as areas vegetadas, representava, diretamente, o valor da porcentagem de cobertura vegetal. Essas medicốs foram realizadas em periodos que variaram de 5 a azdias, com duas medicốs por parcela; o que resultava en 10 repetiGốes por tratamento.

3.11. Indice de área foliar

$$
\text { - indice de área foliar (IAF) refere-se à }
$$
área da superficie da folha ocupada por unidade de área da superfície do solo. As coletas das plantas para a determinacăo do IAF foram realizadas en intervalos de quinze dias, durante o ciclo da cultura. Para medicăo da área foliar dacultura, foi utilizado um perfurador de folhas, com o qual foram tomadas amostras ldiscos de tecido foliar) postas à secagem en estufa de ventilatäo forgada, a uma temperatura de $70^{\circ} \mathrm{C}$, até que atingissen peso constante. O IAF foi determinado, relacionando-se o peso da maté-ria seca da área conhecida dos discos de tecido foliar com - Peso da matéria seca restante, de acordo com recomenda... 6. ôes dE BLACKMAN \& WILSON (1951). 


\subsection{Altura de plantas}

As alturas das plantas foram medidas ao longo do ciclo da cultura, tomando-se a distância entre o topo das folhagens e a superficie do solo.

\subsection{Fitomassa e producấo final}

En todos os tratamentos foram feitas as aval iafóes de acímulo de matéria seca da cultura. As amostragens de plantas para análise de fitomassa foram realizadas durante o ciclo da cultura, amostrando-se a parte aérea de 1,O m de linha de plantio por parcela. O material colhido era pesado depois de seco à $60^{\circ} \mathrm{C}$ por 2 a 3 dias.

A medicăo final da producăo foi feita en uma area de 12,0 me por parcela. Foram retiradas amostras de plantas para determinacáo do número de plantas por área $E$ PESO dE 1000 senEntes (EVANS, 1972).

Também foi determinado o índice de colheita (IC), que é a relacão entre a producăo final de grăos e a natéria seca total, para todos os tratamentos.

A colheita em todas as parcelas foi realizada aos 62 dias após a emergência* 


\section{RESULTADOS E DISCUSSão}

\subsection{Desempento da cultura}

\subsubsection{Fitomassa}

Na Figura 1, encontram-se os resultados da evolufáo de matéria seca na parte aérea para os quatro tratamentos de populaföes da ervilha irrigada. Os resultados se mostram variveis em todos os tratamentos, apesar do tamanho da amostra coletada (5 metros de linhas de plantas por tratamento).

A acumulaça da matéria seca aumentou sempre durante todo o ciclo, em funcäo dos niveis populacionais: os maiores valores ocorreram com os de altas densidades. Porém, as diferencas observadas em cada data näo seguem as mesmas proporfö́s em relafăo t̀s densidades populacionais. No final do ciclo, nấo houve uma tendência de estabilizacăo na acumulacăo da matéria seca em nenhum dos tratamentos. Esse fato é mais evidenciado nos tratamentos de maiores niveis populacionais. O padräo de acumulatäo verificado, possivelmente, seja resultado da grande 


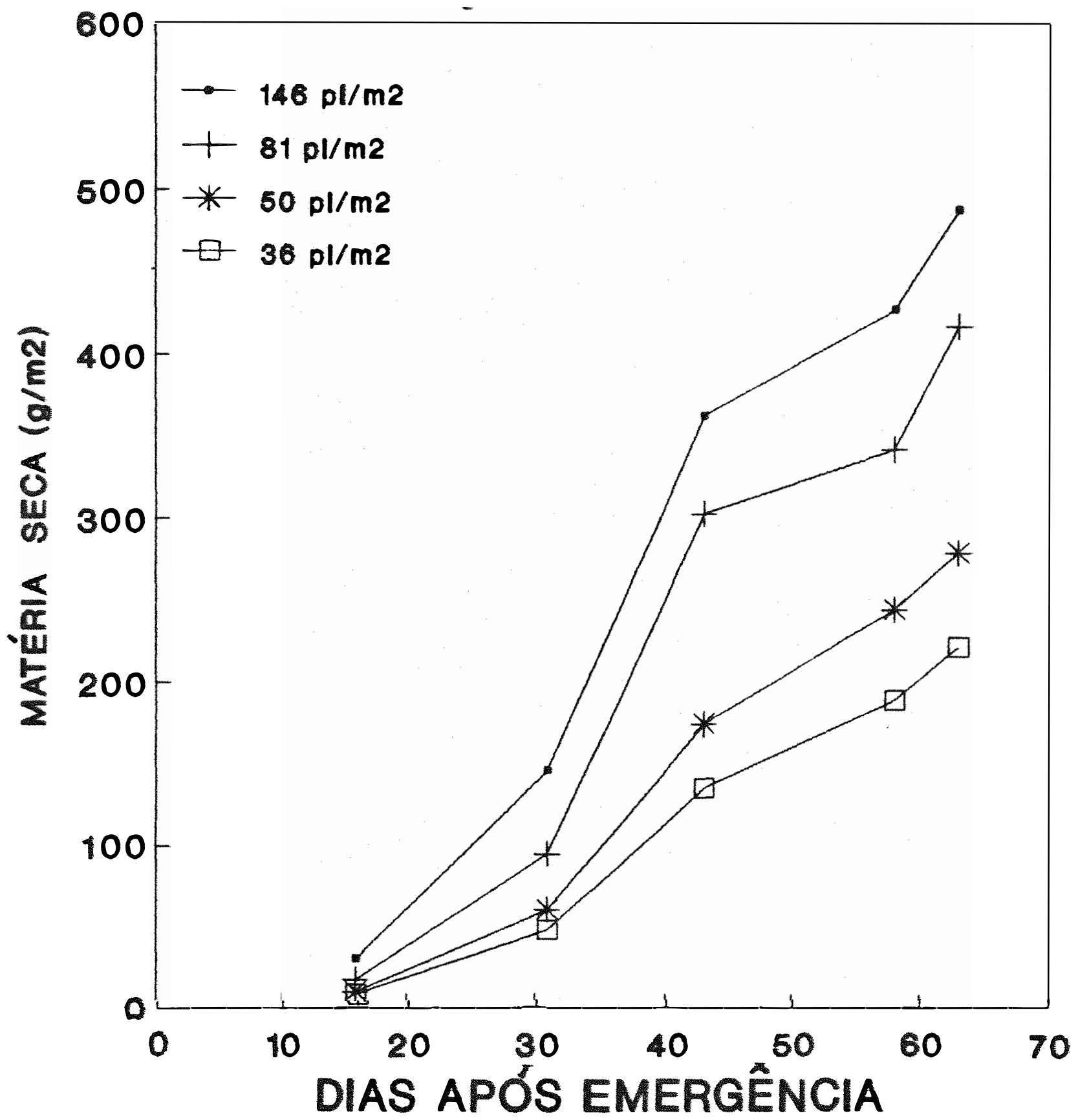

Figura 1. Acimulo de matéria seca (g/me) ao longo do ciclo de desenvolvimento da cultura da erviIha, para as diferentes populacóes, no ano de 1991, Campinas, $S F$. 
precocidade da cultura (69 dias), exacerbado pelo plantio tardio e pelo periodo quente e seco ocorrido no final do ciclo.

A precocidade no ciclo da cultura foi maior nos dois tratamentos de maior densidade populacional, tendo a sua colheita sido realizada com 4 dias de antecedênciล

Por fim, foram obtidas, através da análise de regressäo linear, as equaföes que descrevem o acimulo de matéria seca da ervilha ao longo do tempo, para as diferentes densidades populacionais (Tabela 3 ). O modelo linear foi selecionado em virtude de os resultados näo demonstrarem o típico formato sigmóide da curva de crescimenton

os coeficientes de correlacäo obtidos para cada equacăo mostram que houve correlacăo altamente positiva para todos os tratamentos. Desta forma, as equacóes obtidas poderăo ser utilizadas para as estimativas do acdmulo de matéria seca, quando forem considerados periodose condigöes experimentais similares às do presente estudo. As taxas médias de acúmulo de matéria seca ou taxa de crescinento da cultura, foram de $4,66: 6,0 ; 8,6 \in 9,88$ $9 . m^{-2}$. dia-1, respectivamente para as densidades populacionais de $36,50,81 \in 146 \mathrm{plantas} / \mathrm{m} 2$, mostrando o forte efeito dos tratamentos. 
Tabela 3 - Equacôes de regressấo linear para os tratamentos de diferentes densidades populacionais da cultura da ervilha, para o ano de 1991 em Campinas. $S P$. Mé a matéria seca tgtal $(g(m)\rangle$ e $t$ o número de dias após a emergencia (DAE).

\begin{tabular}{cccc} 
Tratamento & Equacăo regressäo linear & Coef.Correlacáo \\
pl/m? & & & \\
\hline 146 & $M=9.88 t-126.3$ & 0.9812 \\
81 & $M=8.60 t-127.5$ & 0.9717 \\
50 & $M=6.00 t-97.8$ & 0.9895 \\
36 & $M=4.66 t-76.3$ & 0.989
\end{tabular}

4.1.2. Altura de plantas

Houve evolucăo normal da altura de plantas durante todo o ciclo para todos os tratamentos, conforme pode ser visto pela figura 2 . Com excecäo do tratamento de alta densidade populacional (146 plantas/me), năo foram acentuadas as diferengas de altura de plantas, desde o início até o final do ciclo, entre os outros tratamentos. os valores máximos atingidos de altura de piantas para todos os tratamentos ocorreram no inicio da formacăo da producăo, aos 40 dias após emergência, atingin-do resultados que variaram de 25 a $30 \mathrm{~cm}$, entre tratamentos:

No final do ciclo, houve uma queda acentuada da altura de plantas, em todos os tratamentos, resultado do acamamento das plantas que se iniciou no final do estágio de formacăo da producăo, quando as vagens atingiram pesos maiores. 


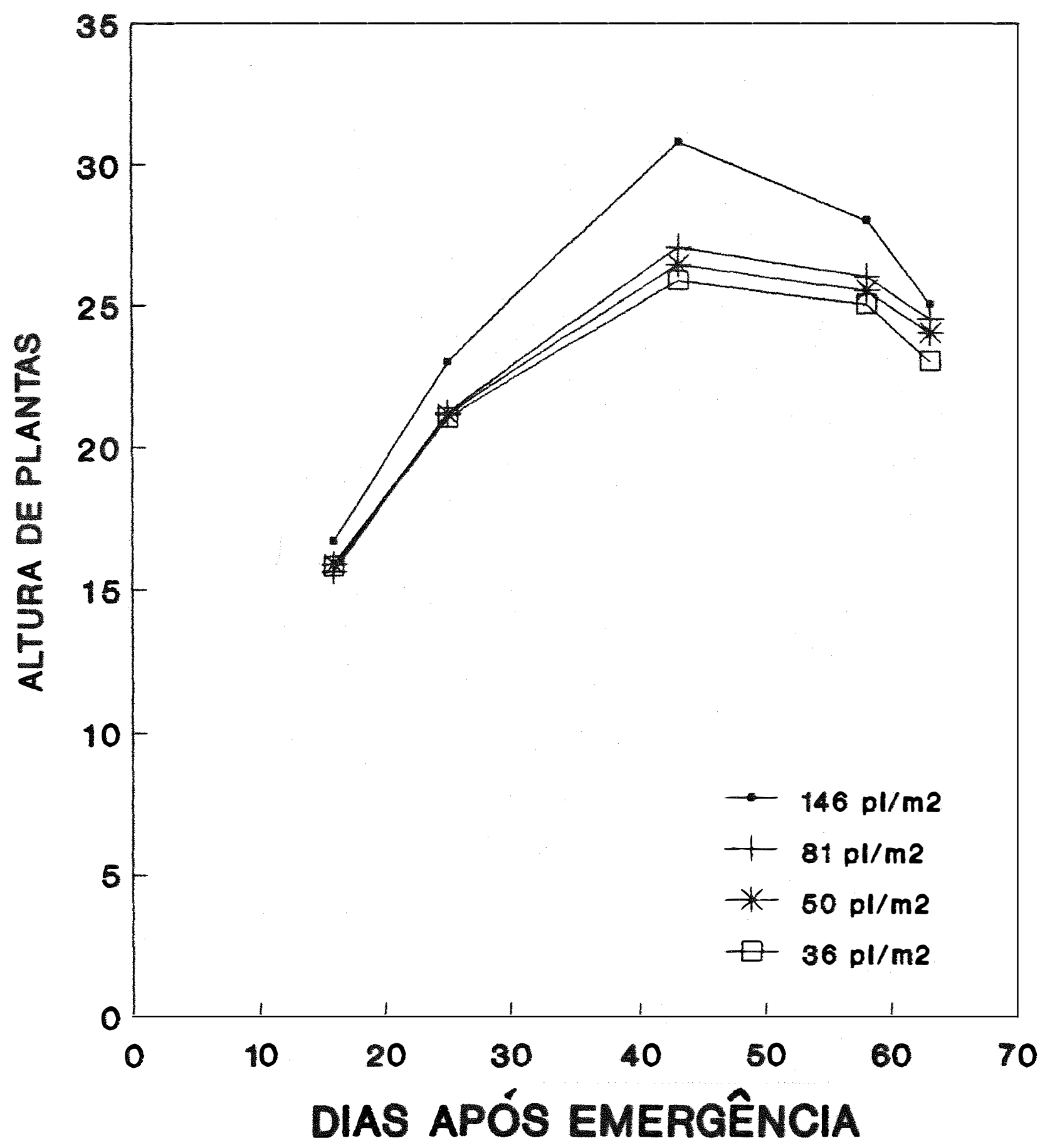

Figura 2. Altura de plantas (cm), ao longo do ciclo de desenvolvimento da cultura da ervilha, para as diferentes popilacóes, no ano de 1991, Camp inas, SP. 


\subsubsection{Indice de área follar (IAF)}

A variacão do IAF ao longo do ciclo de de.... senvolvimento da ervilha é mostrada na Figura 3.

A evolucăo do IAF acompanhou, durante todo o ciclo, a diferenca dos niveis populacionais entre tratamentos. Apesar desta proporcionalidade, os valores máximos at ingidos entre os tratamentos näo foram diretamente proporcionais, sendo de $1,6: 2,3 ; 4,3$ e 5,5 respect ivamente, para as densidades populacionais de $36,50,81$ e 146 plan$t a 5 / m ?$

Os valores máximos de IAF, em todos os tratamentos, foram alcancados no inicio do estágio de forma... c: ลัo da producăo.

Constatou-se que, apesar de o IAF ter at ingido um valor acima de 5 para o tratamento de maior densidade populacional, a cobertura vegetal năo se encontrava completa.

O IAF presente nas plantas mostrou uma reduGăo no terco final do ciclo atingindo valores médios para as densidade populacionais de $146,81,50$ e 36 plantas/me?, respectivamente de $3,8: 2,5: 1,4$ e $1,2$. 


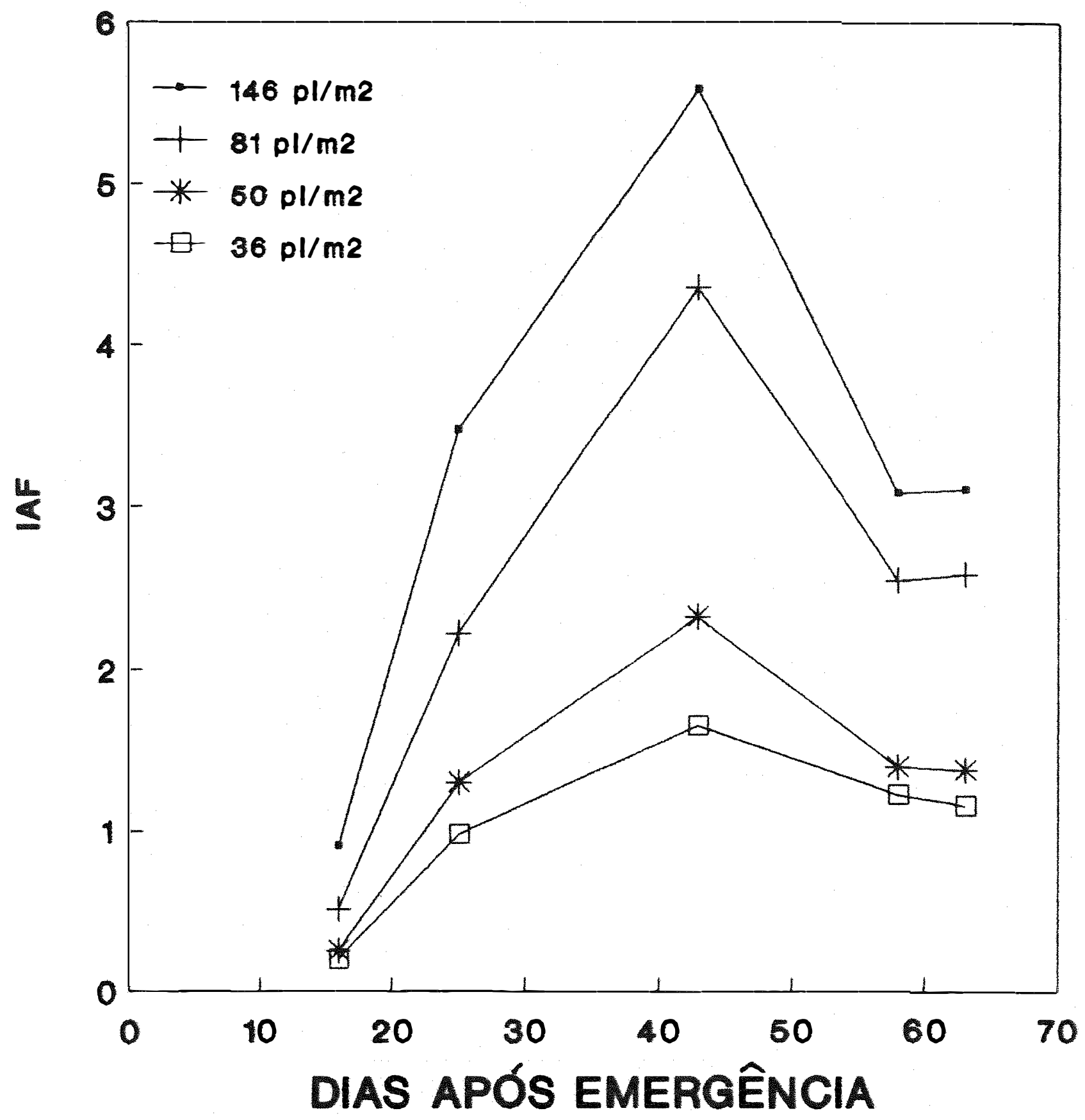

Figura 3. Indice de área foliar ao longo do ciclo de desenvolvimento da cultura da ervilha, para as diferentes populacóes, no ano de 1994 , Campinas, SP. 


\subsubsection{Cobertura vegetal}

A evolucäo da cobertura vegetal ocorrida nos tratamentos de diferentes niveis populacionais é mostrada na Figura 4. As diferencas populacionais, entre os tratamentos, induziran diferencas de cobertura vegetal ao longo de todo o ciclo da cultura. Apesar da alta densidade populacional imposta pelos tratamentos, nenhum deles atingiu a cobertura vegetal completa.

Para os dois tratamentos de maiores densidades populacionais, esperava-se que, durante boa parte do ciclo, fossen alcancados indices de cobertura vegetal completa. Os maiores valores atingidos em todos os tratamentos ocorreram entre a fase final do florescinento e inicio da formacáo da producăo, valores estes de $92,82,56$ e $48 \%$, respectivamente, para os tratamentos de densidades populacionais de $146,81,50$ e 36 plantas/me.

No final dociclo, houve un decréscimo da cobertura vegetal en todos os tratamentos, porém nos dois tratamentos de maiores indices populacionais este decréscimo foi bem nais acentuado que nos outros. Este fato pode ser justificado por diversos fatores, dentre eles, o menor tamanho das folhas, a senescência precoce e possivelnente por um stress hidrico imposto tanto pelo manejo, quanto pela denanda atmosférica maior deste periodo final (Tabelas 1,2 E 3 EM APENDICE. 


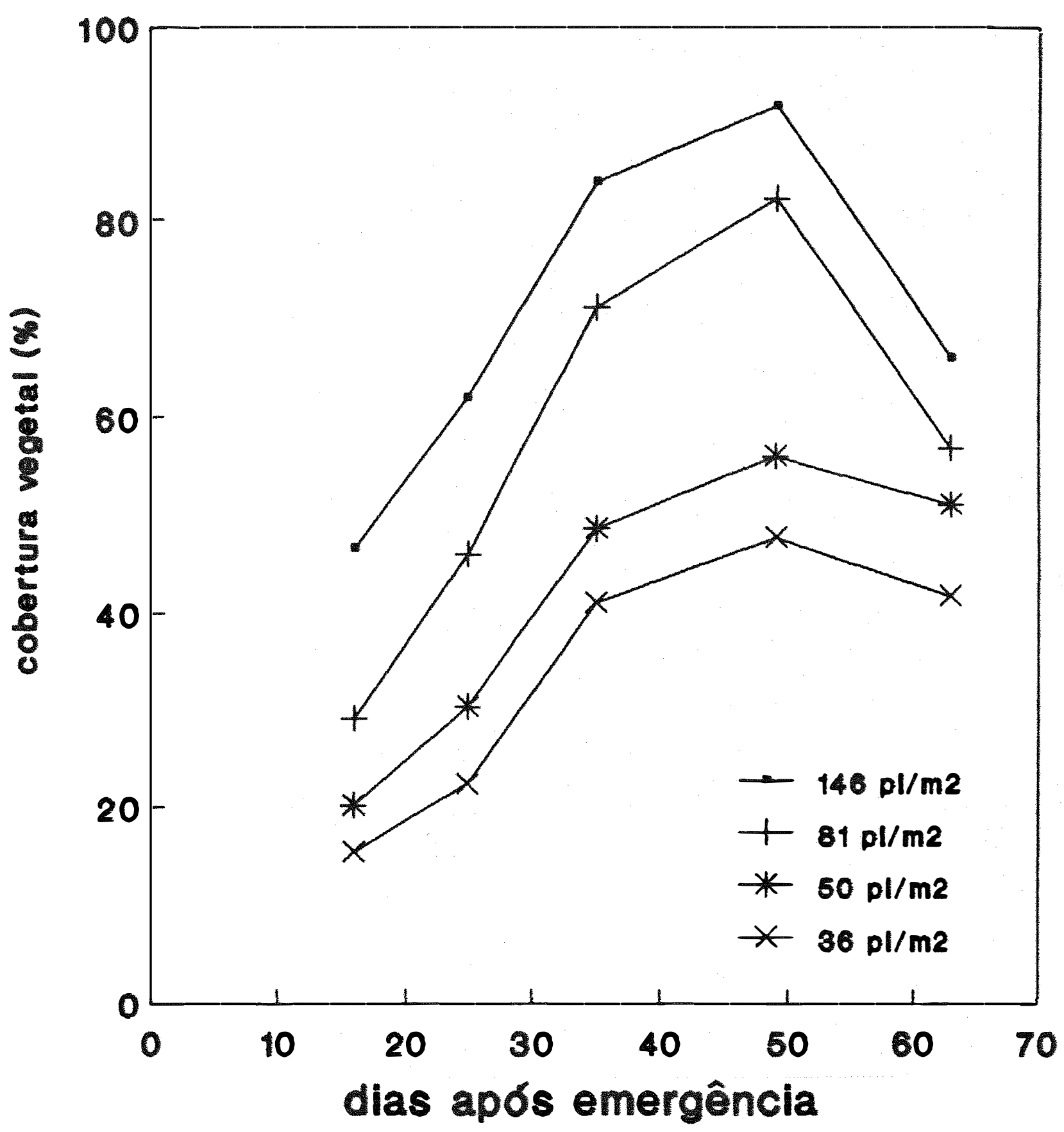

Figura 4. Cobertura Vegetal $(\%)$ ao longo do ciclo de desenvolvimento da cultura da ervilha, para as diferentes populacóes, no ano de 1991 , Campinas, $S P$. 


\subsubsection{Producão final}

Na Tabela 4, encontran-se os resultados de producăo final de gräos obtidos com os tratamentos de di-. ferentes niveis populacionais. A producäo varioude 2557 $\mathrm{kg} / \mathrm{ha}$ para o tratamento de maior densidade populacional, até $1258 \mathrm{~kg} / \mathrm{ha}$ para o de menor. Segundo o INSTITUTTO AGRONOMICO (1987), a produtividade normal esperada, dependendo de um bom manejo da cultura e das condicóes climaticas favoráveis, varia de 1500 a $3000 \mathrm{~kg} / \mathrm{ha}$. WUTKE et alii (1990 e 1991) desenvolveram estudos com diferentes cultivares de ervilha, sob irrigagäo, para as condiföes do Estado de Sáo Paulo. As produtividades máximas alcangadas pelo cultivar Majestic, variaram de 1673 a $1860 \mathrm{~kg} / \mathrm{ha}$. Portanto, a produtividade do presente estudo pode ser considerada bastante satisfatória para condicóes irrigadas.

A baixa precipitacáo ocorrida no ano de. 1991 năo teria permitido una produgăo econômica da cultura sem o auxilio das irrigacöes.

O aumento na produtividade de gräos por tratamento en relagáo à menor densidade populacional 36 plantas/mes) foi respectivamente de 103,41 e $17 \%$ para as densidades de 146,81 e 50 plantas/m?

Os resultados do efeito isolado da densidade populacional sobre alguns componentes da producăo encon-tram-se na Tabela 5. 
Tabela 4 - Producăo final de gräos (kg/ha) para a cultura da ervilha, nos diferentes tratamentos, para o ano de 1991, Campinas, SP.

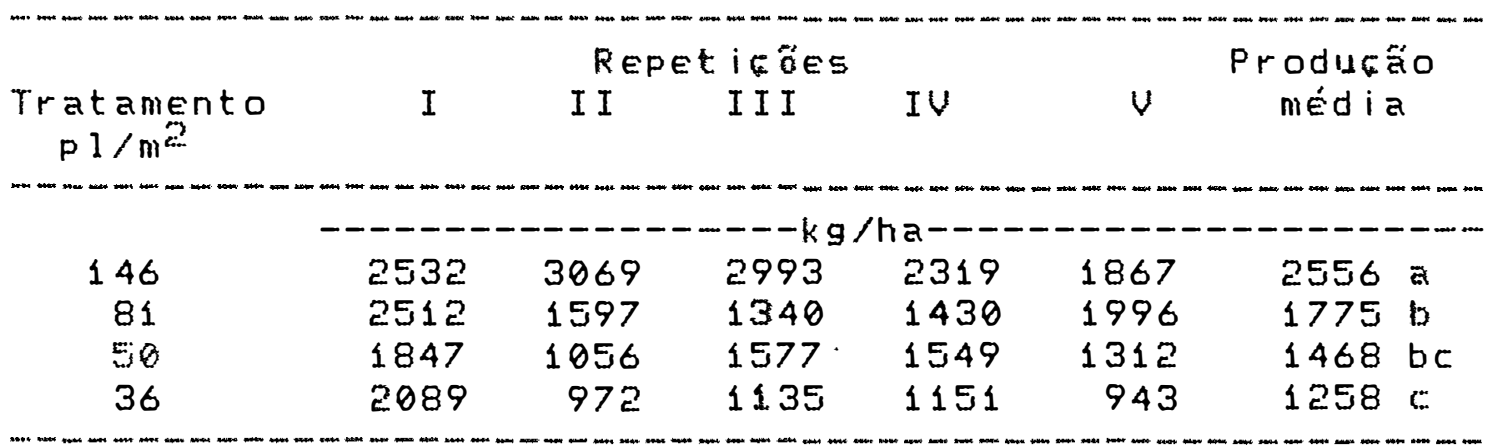

Obs: indices literais idênticos näo diferem entre si pelo te:ste de Duncan ao nivel de $5 \%$.

Tabela 5 - Componentes da producäo para a cultura da ervi-.. lha, nos diferentes tratamentos, para o ano de 1991 en Campinas, SP.

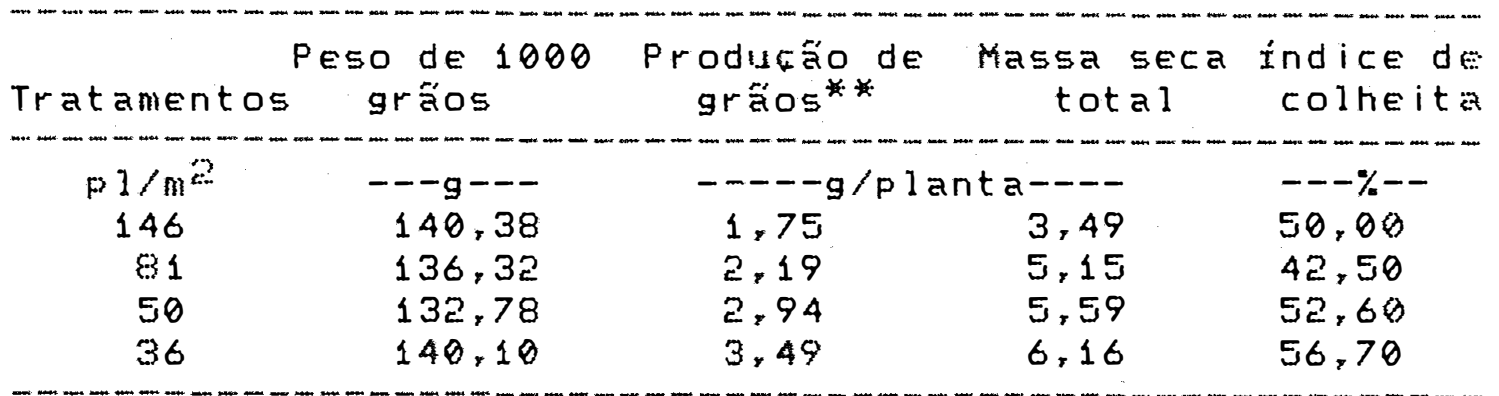

* grä́os com $\theta \%$ de umidade

Observa-se que, d̀ medida que se aumentou a densidade populacional houve um decréscimo, tanto para a producäo de grä́os por planta quanto para o acímido de massa seca total por planta. Os resultados obtidos indicam que quando se aumenta a densidade populacional, atingese um ponto no qual as plantas comecam a competir por alguns fatores essenciais de crescimento, tais como nutriente, luz e água, resultando, desta forma, num decrés... cimo da producáo por planta. 
Quando se faz uma análise do indice de coIheita (IC), observamos a conversáo da matéria seca total em producăo. Neste estudo, quanto maior foi a densidade de semeadura, menor foi o IC. Portanto, os valores gerais próximos de 50\% indicam uma excelente conversáo da matéria seca total em producáo, quando comparada a outras culturas de gräos. Logo, nas condicöes deste ensaio, o rendimento por unidade de área aumentou com o aumento da densidade de seneadura, visto que a redugäo na conversäo de massa seca em producăo, ou mesmo a menor producăo de grä́s por planta, foran amplanente compensados pelo aumento no número de Plantas dos tratanentos.

$$
\text { Ao se fazer uma análise do peso de } 1000
$$

gráos por densidade de semeadura, constatou-se que a va-... riabilidade deste parâmetro ocorrida entre tratanentos, näo esteve relacionada à densidade de semeadura, de forma consistente.

\subsection{Balanco hidrico}

o balanco hidrico de campo foi efetuado para os tratamentos com densidades de plantio de 146,50 e 36 plantas/ne, a intervalos de tempo de acordo com os períoodos de irrigacáo, desde o final do estágio de desenvolvimento vegetativo até o final do ciclo da cultura. Os resultados obtidos sáo apresentados nas Tabelas 6 a 8 . 
Tabela 6 - Componentes do balanco hidrico de campo - precipitacäo, irrigaçó, variacăo do armazenamento de água no solo ( $\Delta A$ ), drenagem profunda e evapotranspiracăo real (ETr) na cultura da ervilha, para o tratamento de densidade de semeadu-.. ra de 146 plantas $/ \mathrm{m}^{2}$, Campinas, SP.

\begin{tabular}{|c|c|c|c|c|c|}
\hline Período & Precipitacáo & Irrigacăo & $\Delta A$ & Dren.Prof. & ETr \\
\hline -dias-- & & & & & \\
\hline $1-05 / 8$ & 0.0 & 28,0 & 12,25 & $0,1.6$ & 15. \\
\hline $7-13 / 8$ & 3,2 & 28.0 & 8.89 & 0,09 & $22+2$ \\
\hline $5-19 / 8$ & 0,0 & 28,0 & 9.67 & $-0,04$ & 18,3 \\
\hline $1-26 / 8$ & 0,0 & 30,0 & 2,62 & 0.50 & 26,8 \\
\hline $3 / 8-2 / 9$ & 0.0 & 30,0 & 0,32 & $-0,07$ & 29,7 \\
\hline $4-09 / 9$ & 0.0 & 20,0 & $-6,04$ & $-0,16$ & 25,8 \\
\hline $1-16 / 9$ & 0,0 & 20,0 & $-0,08$ & $-0,27$ & 20,3 \\
\hline
\end{tabular}

Tabela 7 - Conponentes do balanco hidrico de campo - precipitacäo, irrigactóto, variacăo do armazenamento de água no solo ( $\Delta A$ ), drenagem profunda e evapotranspiracáo real (ETr) na cultura da ervilha, para o tratamento de densidade de semeadura de 50 plantas/me, Campinas, SP.

\begin{tabular}{|c|c|c|c|c|c|}
\hline Período & Precipitacáo & Irrigacăo & $\triangle A$ & Dren.Prof. & ETr \\
\hline -dias-- & ----1 & ----- & & & \\
\hline $1-05 / 8$ & 0,0 & 28,0 & 14,84 & 0,56 & 12,60 \\
\hline $7-13 / 8$ & 3,2 & 28,0 & 4,96 & 0.04 & 26,20 \\
\hline $5-19 / 8$ & 0.0 & 28,0 & 10,48 & 0.17 & 17,35 \\
\hline $1-26 / 8$ & 0,0 & 30,0 & 6,43 & 0.39 & 23,18 \\
\hline $3 / 8-2 / 9$ & 0,0 & 30,0 & 1,48 & 0.48 & 28,04 \\
\hline $4-09 / 9$ & 0.0 & 20.0 & $-1,16$ & 0.01 & 21,15 \\
\hline $1-16 / 9$ & 0.0 & 20,0 & 2.66 & 0.05 & 17.29 \\
\hline
\end{tabular}


Tabela 8 - Componentes do balanco hidrico de campo - precipitacäo, irrigacáo, variacáo do armazenamento de água no solo ( $\mathbf{\Delta} A$ ), drenagen profunda e eva... potranspiracáo real (ETr) na cultura da erviIha, para o tratamento de densidade de semeadu... $r a d e 36$ plantas $/ \mathrm{m}^{2}$, Campinas, SP.

\begin{tabular}{|c|c|c|c|c|c|}
\hline Período & Precipitacáo & Irrigacão & $\Delta A$ & Dren.Prof. & ETr \\
\hline -d i a 5-- & $-0-0-2-1$ & 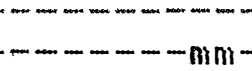 & & . & \\
\hline $1-05 / 8$ & 0,0 & 28,0 & 14,20 & 0,33 & 12,67 \\
\hline $3 / 8$ & 3,2 & 28 & 5.69 & $\theta$, & $8 ?$ \\
\hline 18 & 0.0 & 28,0 & 11,49 & 1,11 & 15,40 \\
\hline $1-26 / 8$ & 0.0 & 30,0 & 8,89 & 0,29 & 20,82 \\
\hline $8 / 8-2 / 9$ & 0,0 & 30,0 & 2.70 & 1.63 & 25,67 \\
\hline 919 & 0.0 & 20.0 & $-2 \times 22$ & 0.43 & 21,79 \\
\hline $1-16 / 9$ & 0,0 & 20.0 & 2,66 & 1,31 & 16,03 \\
\hline
\end{tabular}

A contribuigäo de água no ensaio, deu-se basicamente pela irrigacáo, visto que, durante todo o periodo do ensaio, foram registrados apenas 3 , 3 m de precipitacăo (Tabelas 1,2 e 3 em APÊNDICE). A componente irrigaGăo (I) pode ser considerada como a responsável pelos menores erros ocorridos para os intervalos do balango, pois durante todo o ensaio, for am feitas aplicacóes moderadas d'água permitindo, assim, uma redugâo nas perdas d'água por drenagem profunda.

A variagáo do armazenamento $(\Delta A)$ foi estimada a partir de perfis consecutivos de umidade em volume entre 2 irrigacóes, por meio de amostragens de solo (item 3.7.1). Analisando-se as variacöes de armazenamento entre os tratamentos, percebe-se ter sido esta componente do balango hidricor a que mais afetou os resultados do consumo de água. Certamente, este fato é devido à variacäo do ar-.. 
mazenamento de água no solo estar diretamente ligada ao teor de umidade e tensăo de água no solo.

As perdas de água por drenagem profunda, nos intervalos analisados, foram muito pequenas, e reduziramse à medida que se aumentou a densidade populacional. Este fato pode ser explicado pelo alto controle das irrigafós e a năo interferência das chuvas durante todo o ensaio.

$$
\text { Os dados de evapotranspiracăo real (ETr) }
$$

acumulada, desde o inicio do florescimento até o final do ciclo para os tratamentos da ervilha, variaram de 121,2 a $99,7 \mathrm{~mm}$, mostrando que houve efeito entre as densidades de semeadura. Estes dados en termos de valores médios diários, foram de $3,6: 3,8 \in 4,3 \mathrm{~mm} / \mathrm{d} i a$ para as densidades de semeadura de 36,50 e 146 plantas/men, respectivamente. aumento da ETr por tratamento em relacáo ao de menor densidade de semeadura foi de 5,5 e $19,4 \%$, respectivamente. para as densidades populacionais de 50 e $146 \mathrm{pl} / \mathrm{m}^{2}$.

$$
\text { o naior valor médio de ETr foi de } 4,96
$$
mm/dia para o tratamento de maior densidade de semeadura, no estágio reprodutivo, provavelmente, pelo fato de a cobertura vegetal e IAf terem atingido os seus valores máximos, fatores estes que expóem as plantas a uma maior perda de água para o ambiente, e também, conjuntamente, pelo au-mento das taxas de evapotranspiracäo de referência (ETo).

No final do ciclo, o aumento da ETo nä́o correspondeu, em aumento proporcional da ETr, para nenhum dos 
tratamentos. Este fato, provavelmente, ocorreu como resultado de un efeito contrário da reducäo no IAF (Fig. 3), porcentagem de cobertura vegetal (Fig. 4) e pelo inicioda senescência da cultura. Porém, o tratamento de maior densidade de semeadura apresentou una taxa de ETr superior à dos demais, possivelmente, pelos superiores indices de cobertura vegetal e IAF alcancados pelo mesmo em tal perio-do.

4.3. Coeficiente de cultura

No presente estudo, os valores do coeficiente de cultura para os tratamentos de diferentes niveis populacionais referent-se ao valor basal (kcb). O coeficiente de cultura foi medido 24 horas após as irrigacóes. quando o suprimento de água é adequado à planta, porém a superficie do solo é seca (BURMAN et ali 1980 ; WRIGHT, 1.982).

A diferenca nos coeficientes de cultura basal (kcb) entre os tratamentos de densidades de semeadu... ra diferentes, determinados pelo método de penman modificado, do inicio do florescimento até a maturacăo da er-... vilha, encontram-se na Figura 5 .

Observando-se os valores de kCb (Figura 5 ), nota-se que estes acompanharam as diferencas de nivel populacional imposta pelos tratamentos, sendo os valores 


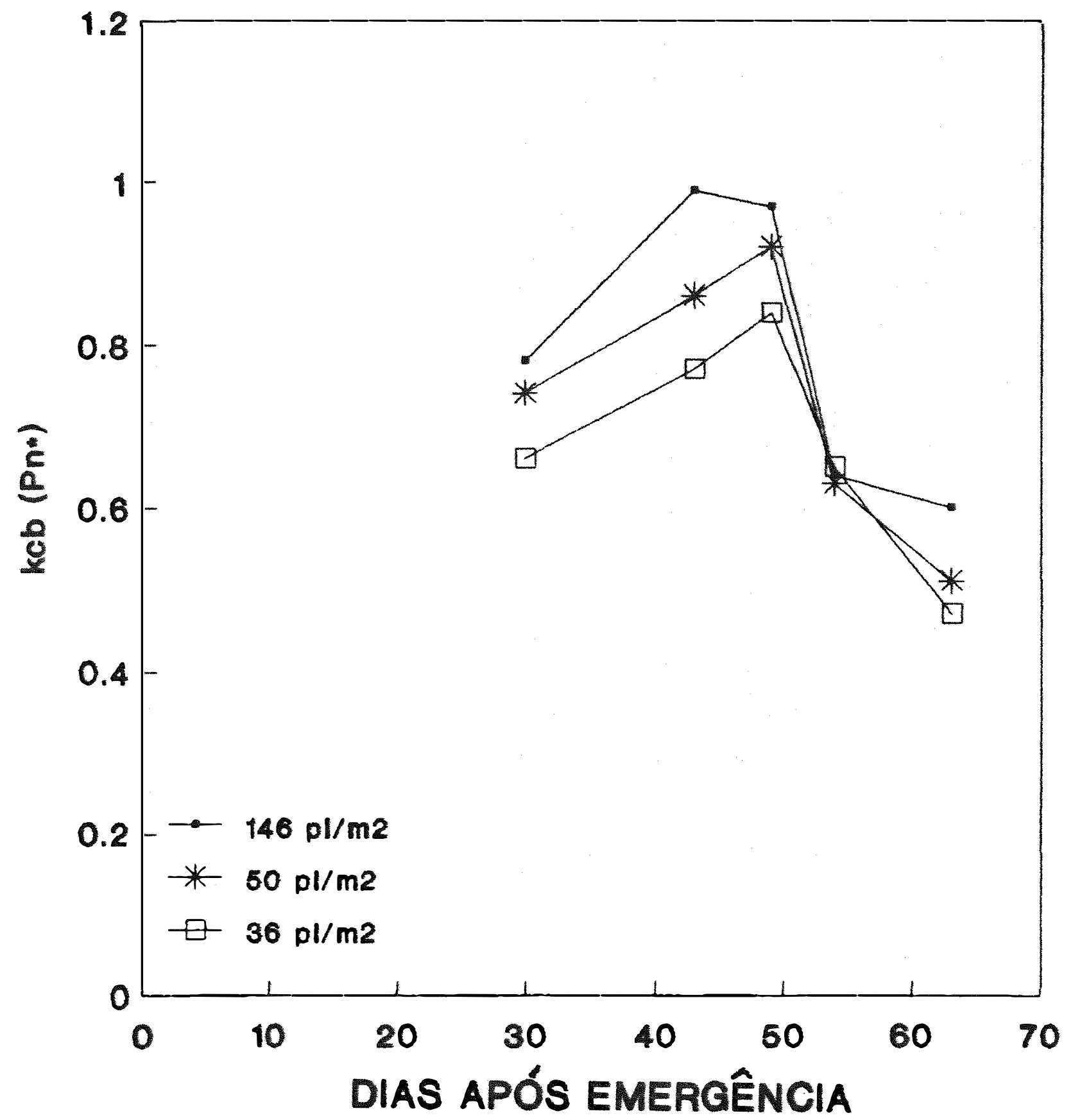

Figura 5. Coeficiente de cultura basal, calculado pelo método do Penman modificado keb(Pn*) desde o inicio do florescimento até o final do ciclo da cultura da ervilha, para as diferentes populafóes, no ano de 1991, Campinas, SP. 
maiores relativos as maiores densidades populacionais. Desta forma, os valores estacionais médios de kcb para os diferentes tratamentos, do inicio do florescimento até a colheita da ervilha, variaram de $0,82: 0,77$ e 0,73 , respectivamente, para as densidades populacionais de 146,50 e 36 plantas $/ \mathrm{m}^{2}$.

Os maiores valores de kcb foram atingidos em todos os tratamentos no periodo de formacáo da producáo. posteriormente à época em que a área foliar da cultura atingiu o valor maximo. Estes valores variaram de $0.97 \%$ $0.92 \in 0,84$, respectivamente, para as densidades populacionais de 146,50 e 36 plantas/m?.

No tergo final do ciclo, houve una queda acentuada nos valores de kcb para todos os tratamentose, basicamente, näo houve diferenga significativa entre os mesmos. Este fato, provavelmente, aconteceu devido à redu... Găo na área foliar e cobertura vegetal, além da ocorrência de stress hidrico provocado pelo aumento das resistências internas ao fluxo de água decorrente da senescência precoce, acamamento e também da alta demanda evaporativa causada pelos baixos valores de umidade relativa (Tabelas 1, 2 e 3 em APÉNDICE). Tendências similares às descritas acima, foram observadas por EL NADI (1974) para as culturas de algodấo e lab-lab, para as condicốes do sudăo.

Os valores médios de ke propostos pela FAO (DOORENBOS \& KASSAN, 1979) variam durante todo o ciclo 
Para a cultura da ervilha de 0,8 a 0.95 , sendo superiores aos aqui determinados. Estes valores recomendados nä́ levam en conta diferencas culturais,tais como as densidades populacionais da cultura impostas pelo presente estudo. bem como a época do ano de cultivo; além do que os valo-.. res de ke proprianente dito, sä́ valores integrados, muito dependentes do manejo de água.

Uma comparacäo entre os resultados de kcb determinados para os diferentes tratamentos foi feita en-tre os dois métodos utilizados para a determinacäo da ETo: método de pennam modificado e do tanque Classe A. A Tabela 9 apresenta essa comparafäo para 5 diferentes períodos durante o ciclo da cultura da ervilha.

A grande discrepância existente entre os valores de kcb para os mesmos tratamentos e periodos expli-. ca-se pela inconsistência existente entre os valores de ETo determinados pelos métodos do tanque classe A e Penmam modificado. Este fato demonstra a inter-relacăo existente entre o valor do kc e o método de determinacăo ut il izado-.. para a evapotranspiracáo de referência que lhe deu or igem. 
Tabela 9 - Coeficientes de cultura basal (kcb) para três diferentes densidades populacionais da ervilha, calculados pelo método de Penmam modificado $\left(P n^{*}\right) \in$ tanque Classe A $(C . A$.$) , en cinco dife-$ rentes periodos do inverno de 1991, Campinas. SP.

\begin{tabular}{|c|c|c|c|c|c|c|c|c|}
\hline \multirow[b]{2}{*}{ Per iodos } & \multicolumn{2}{|c|}{ ETO } & \multicolumn{2}{|c|}{$146 \mathrm{pl} / \mathrm{m}^{2}$} & \multicolumn{2}{|c|}{$50 p 1 / m^{2}$} & \multicolumn{2}{|c|}{$36 \mathrm{pl} / \mathrm{m} ?$} \\
\hline & $C \cdot A$ & $P n^{*}$ & 0 & $P n^{*}$ & $C \cdot A$ & $P n^{*}$ & $C . A$. & $P n^{*}$ \\
\hline & $\cdots-$ & . & & & & & & \\
\hline $5-$ & 3,49 & 4,68 & 1.05 & 0.78 & 0.99 & 0,74 & 0,88 & 0.66 \\
\hline $1-26 / 8$ & 3,75 & 4,51 & 1.19 & 0.99 & 1.03 & $\theta$ & 0.93 & 0,7 \\
\hline $2 / 9$ & 3,70 & 5,10 & 1,34 & 0.97 & 1,26 & 0 , & 1,16 & 0.8 \\
\hline 19 & 3,59 & 5,59 & 1,20 & 0.64 & 0,98 & $\theta_{r}$ & 1,01 & 0.65 \\
\hline $1-16 / 9$ & 59 & 5,68 & 0.94 & 0.60 & 0.80 & 0,51 & 0.74 & 0,47 \\
\hline
\end{tabular}

4.3.1. Relacão entre o coeficiente de cultura basal, a porcentagem de cobertura vegetal e o indice de área foliar.

O valor do coeficiente de cultura basal em funcäo do tempo variou com os tratamentos. Portanto, cer-..tamente deve variar com outras práticas culturais que afetem o porte da planta. Melhor seria se ke fosse expresso Em termos de algum parâmetro da planta, que expressasse o crescimento do dossel vesetativo e a expositão da superficie evapotranspirante ao ambiente. Para tal, foram selecionados dois parâmetros: porcentagem de cobertura vegetal (\%CUeg) e indice de área foliar(IAF).

Para determinacäo das relacóes entre os coe-.ficientes de cultura basal (kcb), a porcentagem de cobertura vegetal e o indice de área foliar (IAF) foi selecion 
nado o intervalo de tempo correspondente ao periodo de crescimento ativo da ervilha, ouseja, de 30 a 49 dias após a emergência. Esta escolha justificada pelo fatode ocorrer um decréscimo nos valores de kcb no final do ciclo (Figura 5), resultado da elevada demanda hidrica com umi... dade relativa mínima ao redor de $30 \%$ (Tabela 3 , Apêndice) e acamamento (Figura 2), que, certamente, promoveram a ocorrência de déficit hidrico, e pela senescência durante estes dias finais com amarelecimento das folhas e redugäo na área foliar ativa (Figura 3 ), fatos estes que näo expressam o coeficiente de cultura basal. Infelizmente, co-. mo a variedade da ervilha estudada apresentou um ciclo bastante curto, o periodo amostrado com crescimento ativo da cultura foi reduzido. Normalmente, o periodo at ivo é predominante no ciclo da cultura.

A relacăo entre o coeficiente de cultura basal (kcb) para os tratamentos de diferentes densidades po-.. pulacionais, em funcáo da cobertura vegetal, é mostrada na Figura 6.

No presente estudo, foi feito um ajuste aos dados da figura 6 , através de programa computacional es... pecifico (ZULLO Jr \& ARRUDA, 1987), obtendo-se como modelo representativo da relagäo entre kcb e a porcentagen de cobertura vegetal (\%CVeg.), a seguinte equacăo:

$$
\begin{array}{r}
\text { kcb }=0,36+0,012(\% \text { cueg. })-0,000063(\% \text { CVeg } 2 \text { (16) } \\
\text { o coeficiente de correlacáo de } 0.85 \text { confirma }
\end{array}
$$




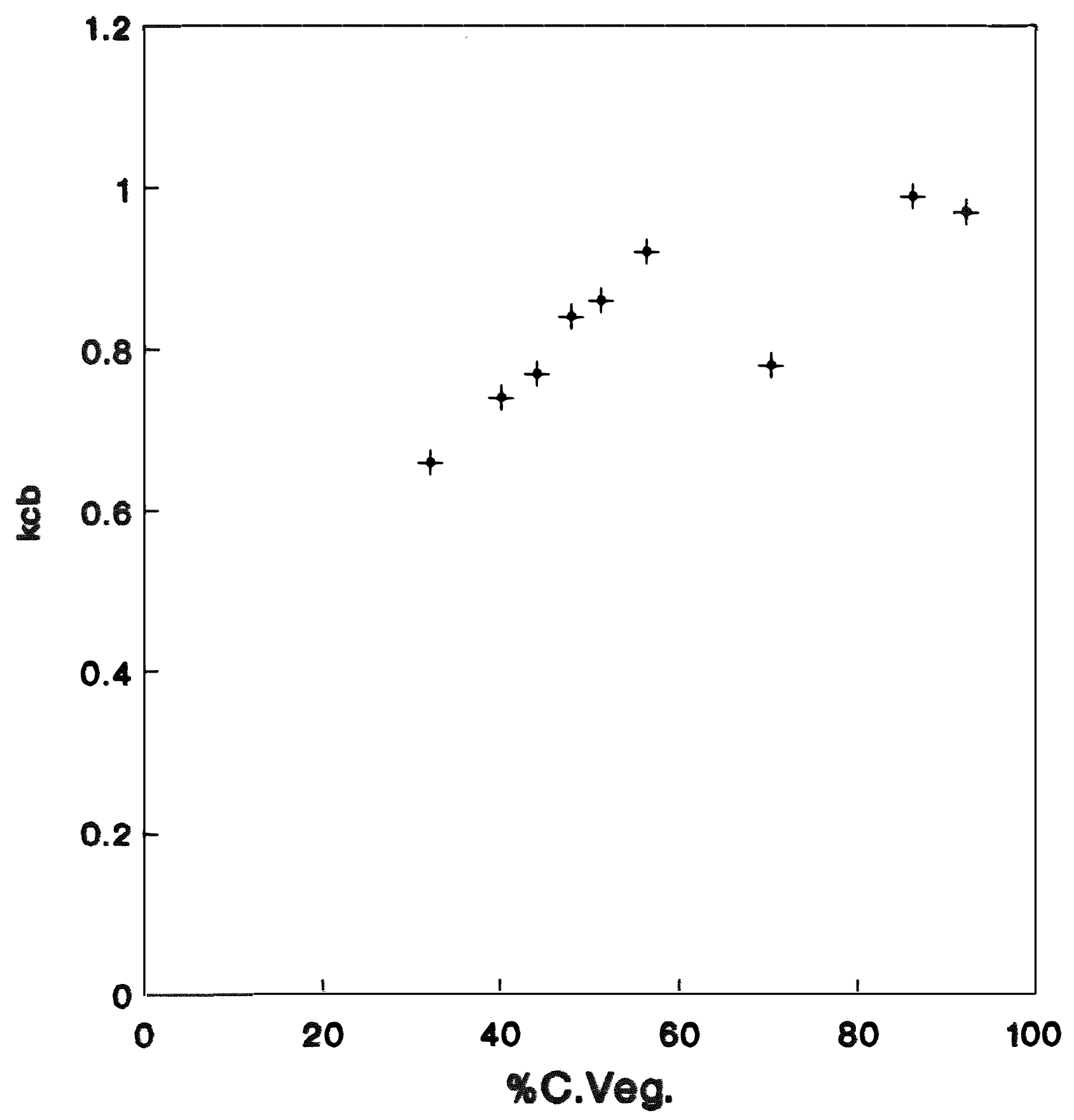

Figura 6. Coeficiente de cultura basal, calculado pelo método de Penman modificado kcb(Pn*) (Fig.5), Em funcăo da cobertura vegetal (Fig.4), para o intervlo de 30 a 49 dias após a emergência, no ano de 1991 , Campinas, SP. 
a existência de correlacăo entre as duas variáveis. Também indica a possibilidade de previsáo de kcb pela avaliacăo do dossel da cultura.

Analisando-se ainda a Figura 6 , observa-se que até aprowimadamente $60 \%$ de cobertura vegetal, o valor do kcb variou de forma linear e crescente com a \%cueg, atingindo um valor máximo próximo à 0.9 ; a partir de en-... täo, houve uma tendência de estabilizacấo no valor do kcb en torno de 0,95 a 1,0 até o ponto en que o solo encontra-va-se quase totalmente vegetado.

Existe similaridade entre esta relacáo de kcb e porcentagem de cobertura vegetal aqui determinada, e os critérios práticos para determinacáo de ke proposto Por ARRUDA (1989), apesar de os valores de kcb determina-.. dos no presente estudo serem um pouco mais elevados. A metodologia em questäo parece ser bastante superior ao simples uso de valores de tabelas como, por exemplo, os da FAO (DOORENBOS \& PRUIT, 1977), amplamente adotados.

A existência de estreita relacăo entre kcb e a porcentagem de cobertura vegetal para a ervilha apresenta concordancia com os resultados obtidos por GOLDBERG (1967) E HEILMAN (1982), respectivamente, para as cultura de amendoime alfafa.

A relacăo entre o coeficiente de cultura basal (kcb) para os tratamentos de diferentes densidades po- 
pulacionais, em funcäo do índice de área foliar é mostrada na figura 7.

$$
\text { Os resultados observados com o IAF säo mais }
$$

variáveis do que os obtidos com a porcentagem de cobertura vegetal. Possivelmente, isto ocorres pelo fato da porcentagen de cobertura vegetal melhor representar os aspectos fisicos do dossel em relagäo a sua exposigäo, principalnente, à radiacáo solar e ao vento, no processo de perdat d'água pela transpiracäo.

Analisando-se a Figura 7, constatou-se um ponto que se apresentou inconsistente con relagáo aos de-mais. Este ponto refere-se ao valor do kcb obtido no primeiro periodo de amostragem no tratamento de maior indice populacional. Náo há uma explicagäo plausivel para ocorrência de tal discrepancia. Este fato aliado à carência de informacóes na faixa que ele representa (IAF entre 2, 5 4,5), dificultou o ajuste de una equacäo geral para a reląăo investigada.

Num esforgo de se quantificar os dados obtidos, optou-se pela representacäo parcial dos dados até o IAF igual a 3 , visto que, até esse ponto, a relacäo entrekcb E IAF apresentou um aumento próximo ao linear, e a partir de entäo, os valores de kcb tenderam a se estabilizar ao redor de 0.95 a 1,0. Para os dados ajustados. foi obtida a seguinte equacáo de regressäo linear:

$$
k \in b=0.49+0.1836 \text { (IAF) }
$$




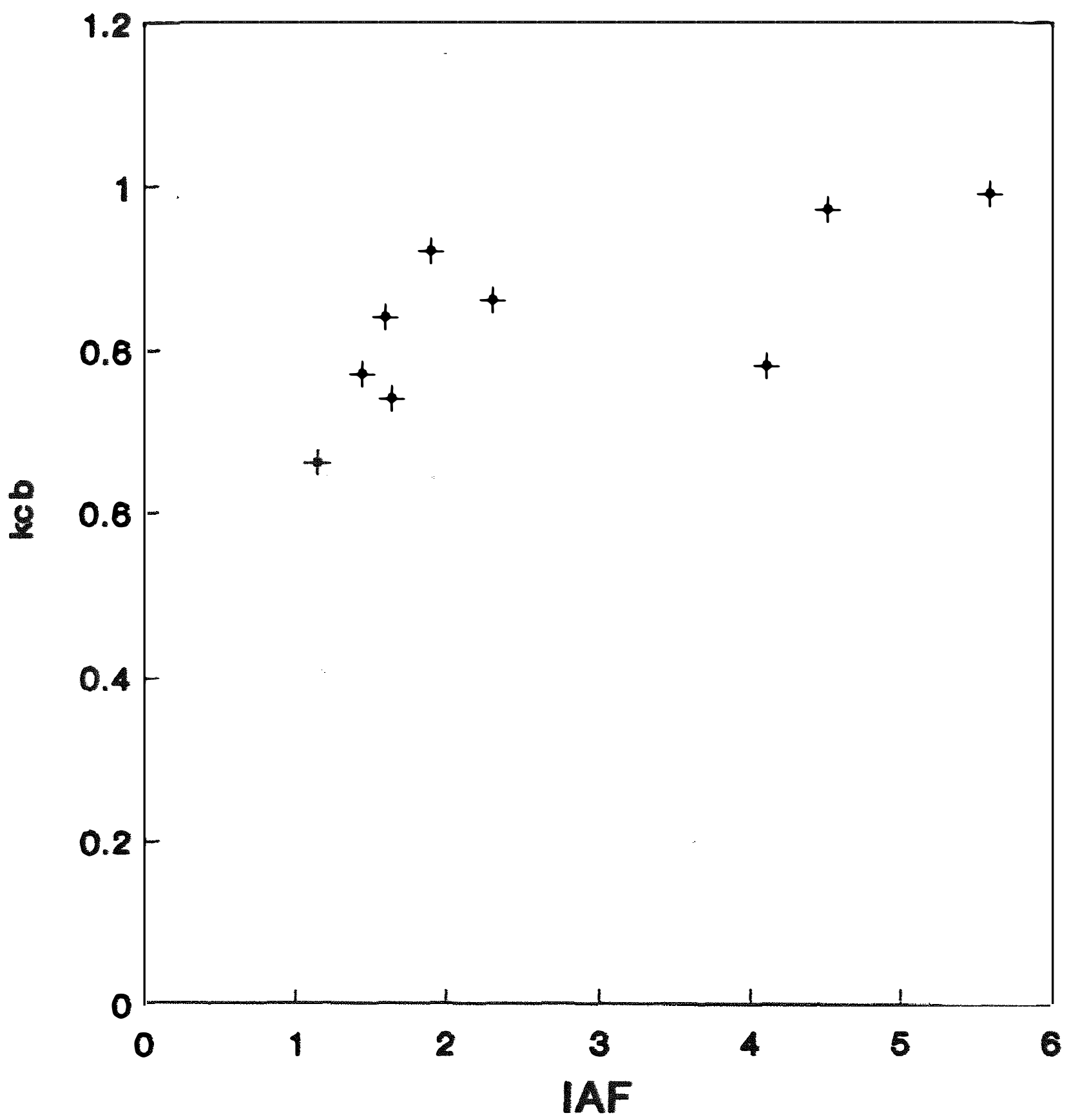

Figura 7. Coeficiente de cultura basal, calculado pelo método de Perman modificado keb(Pn*) (Fig.5), em fungă do indice de área foliar (Fig.3), para o intervalo de 30 a 49 dias após a emergência, no ano de 1999 , Campinas, SP. 
O coeficiente de correlacáo de 0,78 mostra a existência de correlacáo entre as duas variáveis analisadas. Os resultados sugerem um valor inicial de kcb próximo a 0,5 , que é superior àquele indicado pela equacáo (15) com base na porcentagem de cobertura vegetal. Vários autores, dentre eles GOLDBERG (1967). PETRASOUIC (1973), DOORENBOS \& PRUITT (1977), TAN \& FULTON (1980), HEILMAN (1982), ARRUDA (1989) indicam valores de kc oukcb inicial em torno de 0.3. Assims aceitando-se este valor inicial. Ele corrobora para maior consistência na reląấo entre kcb com a porcentagem de cobertura vegetal do que com o indice de área foliar.

Os resultados obtidos no presente trabalio e a sua concordância com outros da literatura demonstram a necessidade de ampliagáo nos estudos das determinacóes do coeficiente de cultura. Para tanto, a metodologia introduzida por BURMAN et ali i (1980) E WRIGHT (1982), assim como os elementos mensuráveis de planta, tipo indice de área foliar e porcentagem de cobertura vegetal, devem ser levados em consideracáo na determinacáo do coeficiente de cultura, com vistas à obtencäo de valores de medicăo do consumo de água das culturas ma is representativos da situacăo de cultivo. 


\section{CONCLUSAOO}

Para as condicóes em que foi conduzido este estudo, pode-se concluir que:

Houve acentuado efeito positivo da densidade de semeadura sobre a produtividade da ervilha Majestic, ciclo curto, e que as maiores producóes da ervilha precoce estariam limitadas às densidades populacionais que náo provocassem acentuado acamanento da cultura.

Houve uma variacáo no consumo de ásua da er..vilha causado pelas diferencas de densidades de semeadura. As taxas médias diárias de Etr, desde o inicio do florescimento até o final do ciclo, para as diferentes densidades populacionais foram de $3.6 \div 3.8$ E $4.3 \mathrm{~mm} / \mathrm{dia}$, respec.... t ivamente, para as densidades de semeadura de 36,506146 p $1 / \mathrm{m}^{2}$

$$
\text { Os valores do coeficiente de cultura basal }
$$

(kcb) variaram com a densidade populacional da cultura e 
com o método de cálculo da evapotranspiracăo de referếncia (ETO) que lhe deu origem.

Os valores médios de kC propostos pela faO (DOORENBOS \& PRUITT, 1977) Sä́ muito superiores aOs valores de kcb determinados neste estudo, sobretudo para o periodo do incio do florescimento até o final da formacáo da producäo, náo atendendo bem às necessidades de manejo.

Existe uma estreita relacăo entre o coefic: iente de cultura basal (kcb) e a porcentagem de cobertura vegetal ( $\%$ C.Veg.) e, também com o IAF, para a cultura de ervilha. O modelo de equacäo que melhor representou esta relacáo no presente estudo é do tipo exponencial quadráti-co em funcäo da porcentagem de cobertura vegetal, com coeficiente de correlacăo de 0.85.

Os resultados obtidos encorajam a ampliacăo dos estudos para outras situacóes de cultivo e culturas, para melhor orientacăo do manejo das irrigacóes. 
REFERÊNCIAS BIBLIOGRAFICAS

ARRUDA, F.B. Uso da água na producăo agricola. In: SIMPósIO SOBRE O MANEJO DE AGUA NA AGRICULTURA, Campinas, 1987. Anais, Editado por A. Glauco. Campinas, Funda6. ลัo Cargil, 1987. P. 177-99.

ARRUDA, F.B. Necessidade da água nas culturas - elemento de projeto. In: CURSO PRATICO INTERNACIONAL DE AGROMETEOROLOGIA PARA OTIMIZACÃO DA IRRIGACÁO, 3., CAMI... pinas, 1989. Instituto Agronônico de Campinas, 1989. $30 P$.

ASSIS, F.N. de. O 1 , do do EVapotranspirômetro no estudo de algumas relacóes entre evapotranspiracăo medida e Estimada. Piracicaba, 1978. 69p. (Doutorado-Escola Superior de Agricultura "Luiz de Queiró"/USP).

ASSIS, F.N. de VERONA, L.A.F. Consumo de água e coeficiente de cultura do sorgo. Pesquisa Agropecuária Brasileira, Brasilia, $26(5): 665-70,1991$. 
BERNARDo, S. Manual de irrigagão. Vicosa, Imprensa Uni-versitária UFV, 1982. 463p.

BLACKMAN, G.E. \& WILSON, G.L. Physiological and ecological studies in the analysis of plant enviroment. Annals of Botany, London, 15: 63-84, 9.951.

BLAD, B.L. Atmospheric demand for water. In: TEARE, I.D. \& PEET, M.M., ed. Crop-water relations. New York, John Willey \& Sons, 1983. Cap 1, P. 15-37.

BRUN, L.S.; KANEMASU, E.T. ; POWERS, W.L. Evapotranspira tion from Soyben and Sorghum fields. Agronomy Journal, Madison, $64(2): 145-8,1972$.

BURMAN, R.D.; NIXON, P.R.; WRIGHT, J.L.; PRUITT, W.O. Water requirements. In: JENSEN, M.E., Ed. Design and operation of farm irrigation systems. St Joseph. ASAE, 1980. Cap. 6, P. 189-232.

CAMARGO, O. A. de; MONIZ, A.C.; JORGE, J.A.; VALADARES, J.M.A.S. Métodos de análise química,mineralógica e física de solos do Instituto Agronômico de Campinas. Campinas, IAC, 1986. 94p. (IAC.Boletim Técnico, 106). 
costa, M.B. da. Determinacấo do consumo de água na cul-tura do trigo (Triticum aestivum L.) através do lisimetro. Piracicaba, 1989. 74p. (Mestrado - Escola Superior de Agricultura "Luiz de Queiróz"/USP).

CURY, D.M. Demanda de água na cultura de repolho (Brassica oleracea var. capitata L.). Piracicaba, 1985. 79p. CDoutorado - Escola Superior de Agricultura "Luia de Queiróz"/USP).

DOORENBOS, J. \& KASSAN, A.H. YiEld reSPONSE to water. Rome, FAO, 1979. 193P. (FAO. Irrigation and Drainage Paper, 33).

DOORENBOS, J. \& PRUITT, W.O. Guidelines for predicting crop water requirements. Rome, FAO, 1977. 144P. (FAO Irrigation and Drainage Paper, 24 ).

DOURADO NETO, D.; JONG-VAN-LIER, Q. dE; BOTREL, T.A.; L.IBARDI, P.L. Curva de retengấo de água no solo: algoritmo em QuickBasic para estimativa dos parâmetros empiricos do modelo de GENUCHTEN; manual de instrucö́s ao 154 ário. Piracicaba, ESALQ, 1990. 33p. 
EL NADI, A.H. The significance of leaf area in evapotranspiration. Annals of Botany, Oxford, 38(156): $607-11,1974$.

ESPINOZA, W. Efeito da densidade de plantio sobre a evapotranspiracáo do milho irrigado na época da secar em cerrado do Distrito Federal. Pesquisa Agropecuária Brasileira, Brasilia, 14(4): 343-50, 1979.

EVANS, G.C. The quantitative analysis of plant growth. Oxford, Blackwell Scientific, 1972. 734p.

FERERES, E. \& UILLALOBOS, F.J. The partitioning of evapotranspiration into evaporation and transpiration for the irrigation scheduling of vegetable crops. In: SYMPOSIUM ON SCHEDULING OF IRRIGATION FOR VEGETABLE CROPS UNDER FIELD CONDITION, Maratea, 1989. Acta Horticulturae, Wageningen, (278): 113-8, June, 1990.

GOLDEERG, B. GORNAT, B. : SADAN, D. Relation between water consumption of peanuts and Class A pan evaporation during the growing season. Soil science, Baltimore, $104(4): 289-96,1967$. 
HANKS, R.J. \& ASHCROFT, G.L. SOIl - plant - atmosphere relations. In: HANKS, R.J. \& ASHCROFT, G.L., Ed. Applied soil physics; soil water and temperature aplications. Berlin, Springer - Verlag, 1980. v.1 cap.4, 1.1. $1-3$ *

HEILMAN, J.L.: HEILMAN, W.E.; MOORE, D.G. Evaluating the crop coefficient using spectral reflectance. Agronomy Journal, Madison, 74: 967-71, 1982.

HILLEL, D. Role of irrigation in agricultural systems. In: STEWART, B.A. \& NIELSEN, D.R., Ed. Irrigation of agricultural crops. Madison. American Society of Agronomy, 1990. Cap.c. P. 5-30.

INSTITUTO AGRONôMICO DE CAMPINAS. InstruEốs agricolas Para o Estado de São Paulo. Campinas, 1987. 233p. (IAC.Bolet im Técnico, 200 ).

JENSEN, M.E. Water consuption by agricultural plants. In: KOZLóWSKI, T.T., ed. Water defits and plant growth. 2.ed. New York, Academic Press, 1969. V.2. cap.1, P. 1-2a. 
JENSEN, M.E.; WRIGTH, J.L.; PRATT, B.J. Estimating soil moistures depletion from climate, crop and soil data. Transactions of the ASAE, St. Joseph, 14: $954-9,1971$.

1..UEBS, R.E.: LAAG, A.E.; NASH, P.A. Evapotranspiration of dryland barley with different plant spacing Patterns. Agronomy Journal, Madison, $67(1): 339-43$, 1975.

MOURA, M.C.F.L. de Determinacăo do consumo de água para a cultura do milho (Zea mays, L) pelo método lisi... métrico. Piracicaba, 1990. 94p. (Mestrado-Escola Superior de Agricultura "Luiz de Queiró"/USP).

MINCHIO, C.A. \& VOLPE, C.A. Evapotranspiracăo máxima $E$ coeficientes de cultura da ervilha (Pisum sativum L.). In: CONGRESSO BRASILEIRO DE AGROMETEOROLOGIA, 5, BE.lém, 1987. Anais: Belém, P.13c-42.

MUALEN, Y. A new model for predicting the hidraulic conductivity of unsaturated porous media. Water Resources. Research, Washington, 12: 513-22, 1976.

OMETTO, J.C. Bioclimatologia vegetal. Säo Paulo, Agrow nômica Ceres, 1980. 440\%" 
Pavani, L.C. Evapotranspiragăo e produtividade en feijoeiro comum (Phaseolus vulgaris L. CV Goiano Precoce) sob três niveis de potencial de água do solo. Piracicaba, 1985. 171p. (Mestrado - Escola Superior de Agri-.. cultura "Luiz de Queiróz"/USPS.

PERES, J.G. Determinagăo dos coeficientes de cultura ( $\left.K_{(e)}\right)$ da cana-de-acícar: ciclo de cana-soca. Piracicaba, 1989. 94p. (Mestrado - Escola Superior de Agricultura "Luiz de Queiróz"/USP).

PETRASOUIC, I. Study of water consumption of cotton in the Euphrates Valley. In: FAO/UNDP REGIONAL SEMINAR ON EFFECTIUE USE OF IRRIGATION WATER AT THE FARM LEVEL, Damascus, 1971. Water use seminar Damascus; re-port. Rome, FAO, 1972. P.111-22. (FAO Irrigation and Drainage Paper, 13 .

PIRES, R.C.M.; ARRUDA, F.B.; BENATTI JR, R:; TOSSELO, R.N. : MEDINA, J.C. Rami: análise de cinco anos de irrigacăo e adubacăo en Campinas. Bragantia, Campinas, $47(2): 341-52,1988$ 
PRUITT, W.0.; LOURENCE, F.J.; VON OETTINGEN, S. Water use by crops as affected by climate and plant factors. California Agriculture, Bekerley, 26(1): 10-4, 1972.

ReICHard, K. Processos de transferência no sistema so10-planta-atmosfera. 4.ed. Campinas. Fundafáo Cargill, 1985. 466P.

RICHARDS, L.A.; GARDNER, W.R.; OGATA, G. Physical processes of determining water loss from soil. Soil Science Society of American Proceedings, Madison, 20 : $310-4,1956$.

SAMIS, T.W.; MAPEL, C.L.; LUGG, D.G.; LANSFORD, R.R.; MCGUCKIN, J.T. Evapotranspiration crop coefficients predicted using growing-degree-days. Transactions of the ASAE, St. Joseph, 28(3):773-80, 1985 .

SEDIYAMA, G.C. Necessidade de água para os cultivos. Brasilia, ABEAS, 1987. 143p. Curso de Engenharia da Irrigacăo. Módulo 4).

SLONEKER, L.L. \& MOLDENHAUER, W.C. MEasuring the amounts of crop residue remainig after tillage. Journal of Soil and Water Conservation, Ankeny, 32: 231-6, 1983. 
TAN, C.S. \& FULTON, J.M. Ratio between evapotranspiration of irrigated crops from flooting lysimeters an Class A pan evaporation. Canadian Journal Plant Science, Ottawa, 60:197-201, 1980.

TANNER, C.B. Measurement of evapotranspiration. In: HAGAN, R.M.; HAISE, H.R. EDMINSTER, T.W., Ed. Irrigation of agricultural lands. Madison. American Society of Agronomy, 1967. Cap. 29, P.534-74. (Agronomy Se-ries, 11)

THORNTHWAITE, C.W. An approach toward a rational classification of climate. Geographical Review, New York, $38: 55-94,1948$.

THORNTHWATE, C.W. \& MATTER, J.R. The water balance. New Jersey, 1955. 104p. (Publication in Climatology. V.3, $n-1)$.

VAN GENUCHTEN, M.Th. A ClOSEd-form Equation for predicting the hidraulic conductivity of unsaturated soils. Soil Sciency Society of American Journal, Madison, 44: $892-8,1980$. 
UILLA NOUA, N.A. OMETTO, J.C. Adaptacăo E simplificaGăo do método de Penman às condicốes climáticas do Estado de São Paulo. In: SIMPósIO BRASILEIRO DE HIDRO-LOGIA E RECURSOS HÍDRICOS, 4. Fortaleza, 1981. Anais. Fortaleza. ABRH, 1981. V.3., P.281-99.

VOLPE, C.A. Coeficientes de cultura (kC) da ervilha (Pisum sativum L.). Ciência Agronômica, Jaboticabal, $1(1): 9,1986$ :

WRIGHT, J.L. NEW Evapotranspiration crop coefficients. Journal of the irrigation and Drainage Division. New York, 108:57-75, 1982.

WUTKE, E.B.; AMBROSANO, E.J.; BULISANI, E.A.; CASTRO, J.L.; GALLO, P.B.; PEREIRA, J.C.U.N.A.; BORTOLETTO, $N_{\text {: }}$ SORDI, G. de. Competicăo de cultivares e linhagems de ervilha de grăos em diferentes regiốes paulis -.. tas. In: REUNIÃO ANUAL DA SOCIEDADE BRASILEIRA PARA O PROGRESSO DA CIÉNCIA, 42., POrto Alegre, 1990. RESHmos. Ciência e Cultura. Suplemento, Rio de Janeiro, $42(7): 13-4,1990$ 
WUTKE, E.B.; AMBROSANO, E.J.; BULISANI, E.A.; CASTRO, J.L.; GALLO, P.B.; PEREIRA, J.C.U.N.A.; SORDI, G dE e BORTOLETTo, N. Espacamento e populacäo de plantas para a cultura da ervilia de gráos em diferentes regiôes paulistas. In: REUNIẤO ANUAL DA SOCIEDADE BRASILEEIRA PARA O PROGRESSO DA CIENCIA, 43, Rio de JanEiro, 1991. Resumos. Cuência e Cultura. Suplemento, Rio de Janeiro, $43(7): 22,1991$.

ZULLO JR: L. \& ARRUDA, F*B. Programa computacional para ajuste de equacöes en dados experimentais. Campinas, IAC, 1987. 3ip. (IAC.Bolet im Técnico, 113). 
APENDICE 
Tabela 1 - Dados Climatológicos do mês de Julho de 1991. Os termos $P$. Pi e Etanque representam, respectivamente, a precipitacáo, a evaporacăo diária medida em evapor imetro de piché a avaporacäo diária medida em tanque Classe $A$.

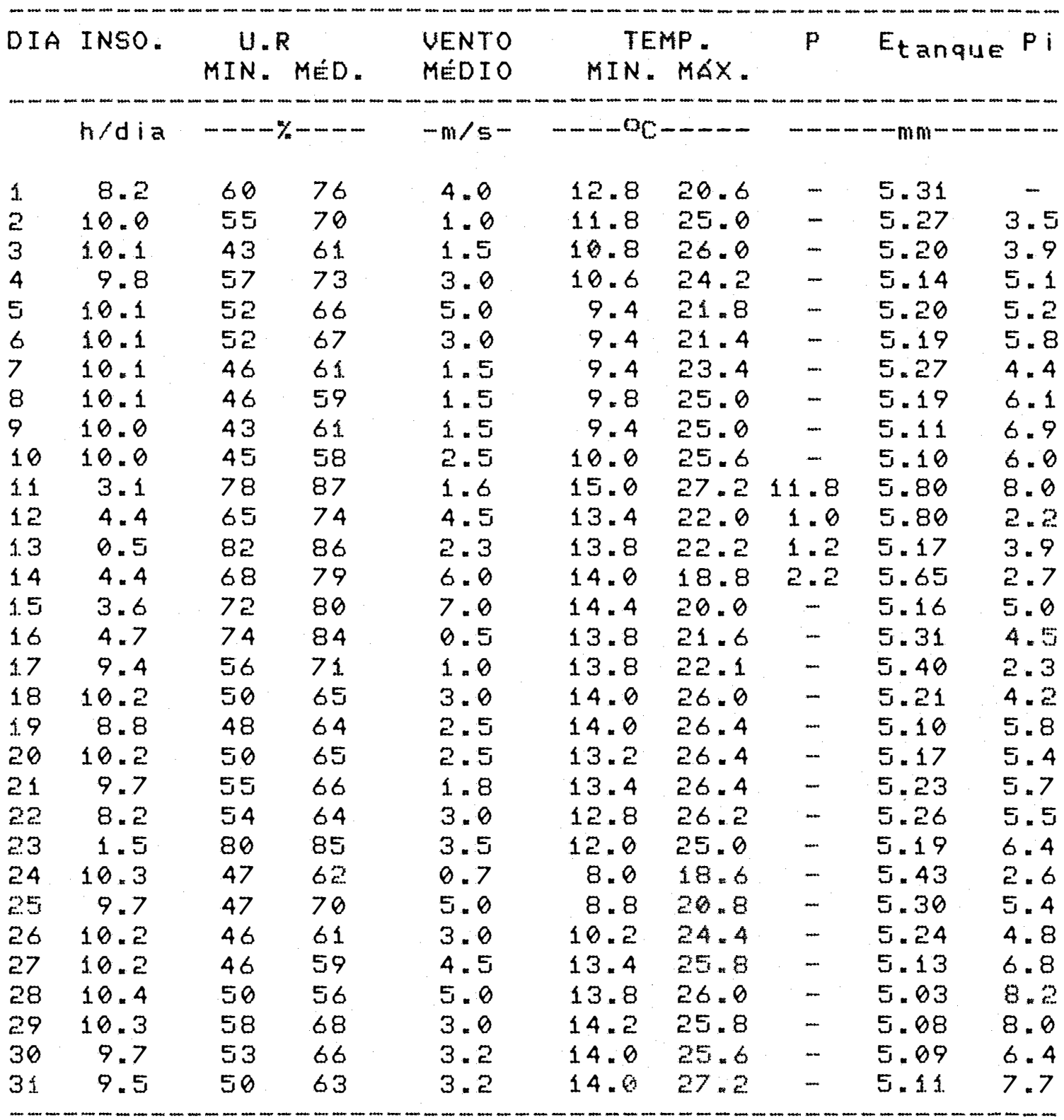


Tabela 2 - Dados Climatológicos do mês de Agosto de 1991. os termos $P$. Pi E Etanque representam, respectivanente, a precipitacáo, a evaporacáo diária nedida en evapor ínetro de piché e a evaporacáo diária medida em tanque Classe A.

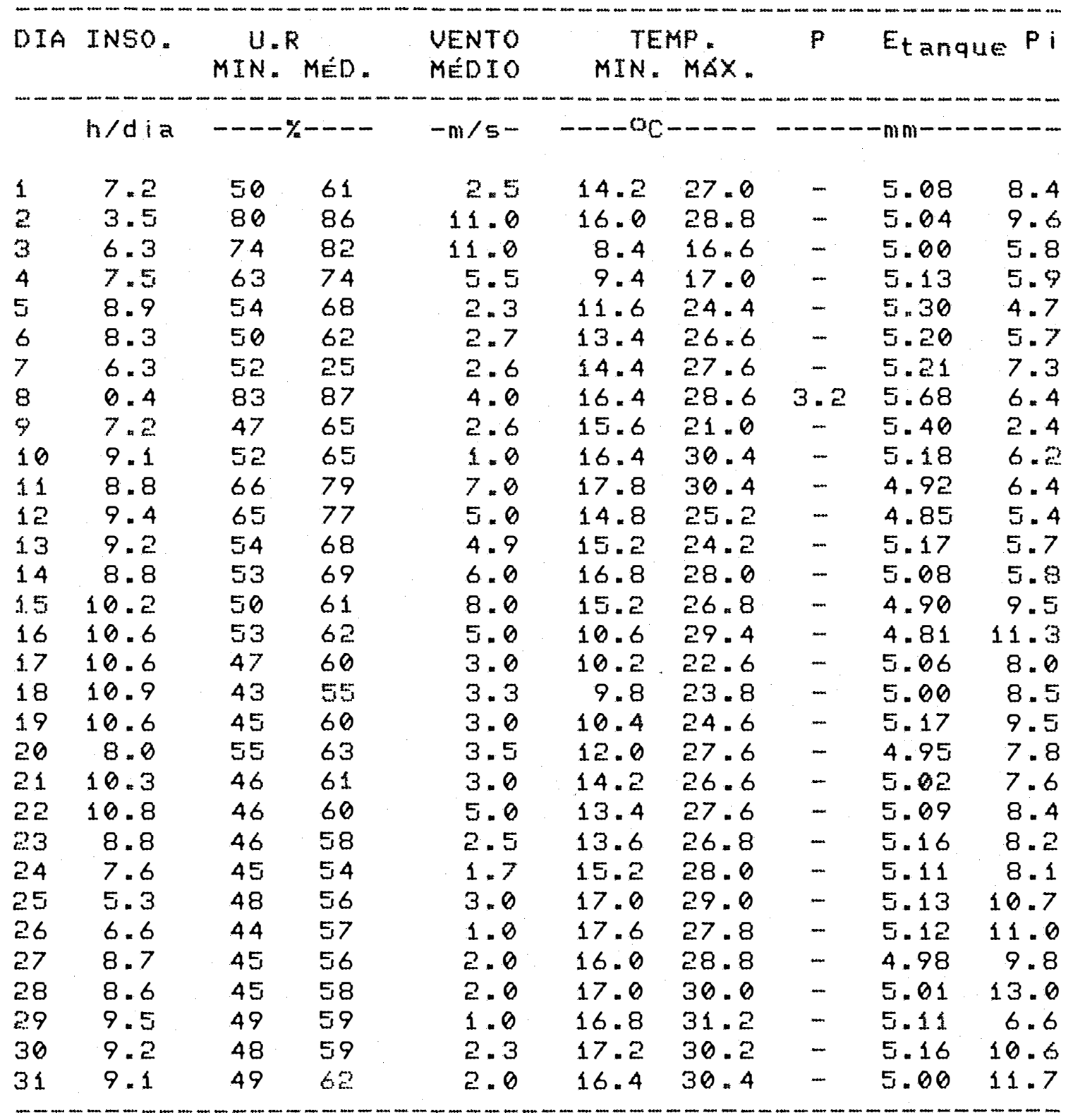


Tabela 3 - Dados Climatológicos do mês de setembro de 1991. Os termos P. Pi E Etanque representam. respectivamente, a precipitacá, a evaporacáo diár ia medida em evaporimetro de piché e a evaporacáo diária medida em tanque Classe A.

\begin{tabular}{|c|c|c|c|c|c|c|c|c|c|}
\hline \multirow[t]{2}{*}{$D I A$} & INSO. & \multicolumn{2}{|c|}{$\begin{array}{l}\text { U.R. } \\
\text { MIN. MÉD. }\end{array}$} & $\begin{array}{l}\text { UENTO } \\
\text { MÉDIO }\end{array}$ & \multicolumn{2}{|c|}{ TEMP : } & $P$ & \multicolumn{2}{|c|}{$E_{t \text { anque }} \mathrm{Pi}$} \\
\hline & h/dia & \multicolumn{2}{|c|}{$----\%----$} & $-m / s-$ & \multicolumn{2}{|c|}{$-\cdots-{ }^{\circ} \mathrm{C}-\cdots$} & $\cdots$ & $-m m i$ & 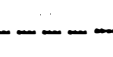 \\
\hline 1 & 6.4 & 72 & 80 & 4.0 & 16.4 & 30.6 & - & 5.0 & 14.2 \\
\hline 2 & 0.6 & 70 & 76 & 12.0 & 14.8 & 25.4 & - & 5.0 & 9.1 \\
\hline 3 & 7.9 & 60 & 72 & 7.0 & 13.6 & 20.6 & - & - & 8.9 \\
\hline 4 & 10.4 & 44 & 59 & 2.5 & 11.8 & 24.6 & - & 5.0 & 7.5 \\
\hline 5 & 10.4 & 40 & 53 & 5.5 & 12.2 & 26.0 & -. & 4.88 & 9.4 \\
\hline 6 & 10.7 & 34 & 50 & 4.0 & 11.6 & 27.2 & - & 4.98 & 15.4 \\
\hline$y$ & 10.6 & 37 & 52 & 2.3 & 1.2 .0 & 28.4 & - & 4.97 & 12.5 \\
\hline 8 & 5.3 & 37 & 52 & 3.3 & 13.2 & 29.0 & - & 5.01 & 12.5 \\
\hline 9 & 8.3 & 52 & 66 & 7.0 & 14.0 & 28.8 & - & 5.22 & 12.1 \\
\hline 10 & 7.5 & 51 & 68 & 5.0 & 13.8 & 26.0 & - & 4.97 & $11 .\{$ \\
\hline 11 & 10.3 & 31 & 50 & 3.0 & 14.4 & 27.6 & - & 5.07 & 7.8 \\
\hline 12 & 10.2 & 45 & 56 & 4.0 & 13.6 & 30.0 & - & 4.80 & 10.1. \\
\hline 1. 3 & 10.8 & 30 & 47 & 4.0 & 12.0 & 28.8 & - & 4.86 & 14.6 \\
\hline 14 & 9.5 & 31 & 45 & 0.8 & 13.0 & 30.2 & - & 5.01 & 10.7 \\
\hline 1.5 & 9.6 & 40 & 49 & 1.6 & 14.0 & 32.0 & - & 5.11 & 12.9 \\
\hline 16 & 2.8 & 49 & 62 & 1.6 & 16.8 & 30.8 & - & 4.85 & 14.5 \\
\hline 17 & 9.3 & 52 & 64 & 5.8 & 16.6 & 30.6 & - & 5.23 & 10.1 \\
\hline 18 & 6.8 & 46 & 57 & 4.0 & 17.2 & 31.8 & - & 5.01 & 9.8 \\
\hline 1.9 & 0.0 & 90 & 92 & 1.0 & 17.4 & 33.2 & 9.8 & 5.80 & 9.7 \\
\hline 20 & 9.9 & 60 & 69 & 5.0 & 15.0 & 18.6 & 13.0 & 5.80 & 2.0 \\
\hline 21 & 10.3 & 47 & 57 & 2.0 & 13.8 & 23.6 & - & 5.01 & 5.6 \\
\hline 22 & 9.0 & 45 & 57 & 2.0 & 15.0 & 27.6 & - & 5.03 & 5.5 \\
\hline 23 & 9.1 & 47 & 65 & 4.0 & 16.4 & 28.6 & - & 4.93 & 7.4 \\
\hline 24 & 7.2 & 70 & 74 & 9.0 & 17.0 & 29.6 & - & 4.80 & 8.3 \\
\hline 25 & 2.9 & 90 & 85 & 7.5 & 15.4 & 28.0 & - & 4.93 & 7.6 \\
\hline 26 & 10.0 & 60 & 70 & 7.0 & 14.4 & 22.2 & 7.8 & 5.80 & 3.9 \\
\hline 27 & 10.6 & 43 & 55 & 3.5 & 13.8 & 23.8 & - & 4.83 & 7.9 \\
\hline 28 & 3.7 & 47 & 71 & 2.5 & 15.2 & 29.6 & - & 4.92 & 7.8 \\
\hline 29 & 0.8 & 91 & 88 & 1.0 & 17.4 & 32.0 & 1.8 & 5.31 & 5.8 \\
\hline 30 & 0.2 & 92 & 93 & 1.0 & 18.8 & & 15.8 & 5.80 & 1.0 \\
\hline
\end{tabular}

